\title{
Metallurgy and Mechanism of Underwater Wet Cutting Using Oxidizing and Exothermic Flux-Cored Wires
}

\author{
Sergey G. Parshin ${ }^{1, * \mathbb{C}}$, Alexey M. Levchenko ${ }^{2}$ and Pengfei Wang ${ }^{1}$ \\ 1 Institute of Mechanical Engineering, Materials, and Transport, Peter the Great St. Petersburg Polytechnic \\ University, 195251 St. Petersburg, Russia; van2.p@edu.spbstu.ru \\ 2 Department of Underwater Welding and Technologies, Educational Scientific and Technical Center "Svarka", \\ 195251 St. Petersburg, Russia; lab@untc-svarka.ru \\ * Correspondence: parshin@spbstu.ru; Tel.: +7-812-552-63-55
}

Citation: Parshin, S.G.; Levchenko, A.M.; Wang, P. Metallurgy and Mechanism of Underwater Wet Cutting Using Oxidizing and Exothermic Flux-Cored Wires. Materials 2021, 14, 4655.

https://doi.org/10.3390/ma14164655

Academic Editors: Dariusz Fydrych and Shinichi Tashiro

Received: 16 July 2021

Accepted: 10 August 2021

Published: 18 August 2021

Publisher's Note: MDPI stays neutral with regard to jurisdictional claims in published maps and institutional affiliations.

Copyright: (C) 2021 by the authors Licensee MDPI, Basel, Switzerland This article is an open access article distributed under the terms and conditions of the Creative Commons Attribution (CC BY) license (https:// creativecommons.org/licenses/by/ $4.0 /)$.

\begin{abstract}
This paper considers the metallurgical processes of dissociation, ionization, oxidation, deoxidation, and dissolution of oxides during underwater wet cutting. A multiphase mechanism of underwater wet cutting consisting of working and idle cycles of the electrical process in a pulsating vapor gas bubble is proposed. A model of arc penetration into metal due to metal oxidation and stabilization of the arc by the inner walls of a narrow kerf is proposed. For underwater cutting of $10 \mathrm{KhSND}$, 304L steel, CuAl5, and AlMg4.5Mn0.7 alloy, we provide a principle of modeling the phase composition of the gas mixture based on high oxygen concentration, improving ionization, enthalpy, heat capacity, and thermal conductivity of plasma through the use of a mixture of $\mathrm{KNO}_{3}, \mathrm{FeCO}_{3}$ and aluminum. The method of improving the thermophysical properties and ionization of plasma due to the exothermic effect when introducing $\mathrm{Fe}_{3} \mathrm{O}_{4}, \mathrm{MoO}_{2}, \mathrm{WO}_{2}$ oxides and $\mathrm{Al}, \mathrm{Mg}$, Ti deoxidizers is proposed. Although a negative effect of refractory slag was revealed, it could be removed by using the method of reducing surface tension through the ionic dissolution of refractory oxides in $\mathrm{Na}_{3} \mathrm{AlF}_{6}$ cryolite. In underwater cutting of $10 \mathrm{KhSND}$ and $304 \mathrm{~L}$, the steel welding current was 344-402 A with a voltage of 36-39 V; in cutting of $\mathrm{CuAl} 5$ and AlMg4.5Mn0.7 alloy, the welding current was 360-406; $240 \mathrm{~A}$, with a voltage of 35-37; $38 \mathrm{~V}$, respectively, with the optimal composition of flux-cored wire: $50-60 \% \mathrm{FeCO}_{3}$ and $\mathrm{KNO}_{3}, 20-30 \%$ aluminum, $20 \% \mathrm{Na}_{3} \mathrm{AlF}_{6}$. Application of flux-cored wires of the $\mathrm{KNO}_{3}-\mathrm{FeCO}_{3}-\mathrm{Na}_{3} \mathrm{AlF}_{6}-\mathrm{Al}$ system allowed stable cutting of $10 \mathrm{KhSND}$, AISI 304L steels, and CuAl5 bronze with kerf width up to $2.5-4.7 \mathrm{~mm}$.
\end{abstract}

Keywords: underwater wet cutting; flux-cored wire; metallurgical processes; electric arc

\section{Introduction}

Underwater welding and cutting are used in the construction and repair of important objects, including offshore oil and gas platforms, wind farms, ports, hydraulic structures, underwater oil and gas pipelines, and the lifting and repair of ships [1]. Underwater welding and cutting are often performed manually by diver-welders using coated and tubular electrodes. Cutting is used to remove defective metal; after cutting, welding is performed on the cut edges of the parts. During underwater wet cutting, steel is thermally affected and saturated with hydrogen. The presence of impurities, slag, and metal hydrogenation worsens the quality of welding and reduces strength, ductility, and impact toughness [2]. Underwater wet welding is complicated by hydrogen-induced cold cracks, porosity, slag inclusions, and delayed hydrogen embrittlement [3-5].

The most commonly used methods for underwater cutting are manual arc cutting with coated electrodes, manual oxy-arc cutting with tubular and exothermic electrodes, semi-automatic arc cutting with flux-cored wire, gas-oxygen, automatic plasma cutting, laser cutting, electromechanical cutting, electrohydraulic cutting, explosion cutting, wire cutting, and other methods [6-10], as shown in Table 1. 
Table 1. Parameters of methods for underwater wet cutting of steels [6-10].

\begin{tabular}{|c|c|c|c|c|c|}
\hline Method & $\begin{array}{l}\text { Maximum } \\
\text { Thickness of } \\
\text { Steel, mm }\end{array}$ & Current, A & Voltage, V & $\begin{array}{c}\text { Oxygen } \\
\text { Consumption, } \\
\mathrm{m}^{3} / \mathrm{h}\end{array}$ & $\begin{array}{l}\text { Cutting Speed for } \\
\text { Steel, } \mathrm{mm} / \mathrm{min}\end{array}$ \\
\hline $\begin{array}{l}\text { Manual oxy-arc cutting } \\
\text { using tubular electrodes of } \\
8 \mathrm{~mm}\end{array}$ & 100 & $180-350$ & $25-45$ & $0.8-1$ & $\begin{array}{c}30-40 \\
\text { (for } 10 \mathrm{~mm} \text { ) }\end{array}$ \\
\hline $\begin{array}{c}\text { Manual oxy-arc cutting } \\
\text { using exothermic } \\
\text { electrodes of } 9.5 \mathrm{~mm}\end{array}$ & 35 & $150-300$ & $25-45$ & $12-60$ & $\begin{array}{c}400-500 \\
\text { (for } 10 \mathrm{~mm} \text { ) }\end{array}$ \\
\hline $\begin{array}{l}\text { Manual arc cutting using } \\
\text { coated electrodes of } 4 \mathrm{~mm}\end{array}$ & 16 & $200-280$ & $30-45$ & - & $\begin{array}{c}60-80 \\
\text { (for } 10 \mathrm{~mm} \text { ) }\end{array}$ \\
\hline Automatic plasma cutting & 80 & $300-800$ & $200-300$ & $\begin{array}{l}\text { Air consumption } \\
\text { of } 0.06-0.12\end{array}$ & $\begin{array}{c}300-400 \\
\text { (for } 15 \mathrm{~mm} \text { ) }\end{array}$ \\
\hline Automatic laser cutting & 100 & Power of $2-10 \mathrm{~kW}$ & - & $\begin{array}{l}\text { Air consumption } \\
\text { of } 0.1-0.3 \mathrm{~m}^{3} / \mathrm{h}\end{array}$ & $\begin{array}{c}300-1000 \\
\text { (for } 15 \mathrm{~mm} \text { ) }\end{array}$ \\
\hline $\begin{array}{c}\text { Semi- } \\
\text { automatic/automatic } \\
\text { cutting using flux-cored } \\
\text { wires of } 2 \mathrm{~mm}\end{array}$ & 20 & $300-500$ & $32-42$ & - & $\begin{array}{c}70-250 \\
\text { (for } 10 \mathrm{~mm} \text { ) }\end{array}$ \\
\hline
\end{tabular}

The mechanism of underwater wet cutting was previously studied in other works [11,12]. Technological properties of flux-cored wires of 2 and $2.4 \mathrm{~mm}$ in diameter based on $\mathrm{Ba}(\mathrm{OH})_{2} \cdot 8 \mathrm{H}_{2} \mathrm{O}$ and $\mathrm{Na}_{2} \mathrm{SiO}_{3}$ were studied at the current of 450-600 A, voltage $50-55 \mathrm{~V}$, and wire feed rate of 3.5-6 m/min when cutting steel of 10-20 $\mathrm{mm}$ in thickness. The authors proposed a scheme of underwater wet cutting, according to which the flux-cored wire during cutting deepens into the metal and forms a kerf.

The analysis of patents for inventions shows a great variety of chemical compositions of flux-cored wires. One of the wires with the filling factor of $16-18 \%$ has the composition, wt.\%: 40-60 saltpeter (sodium nitrate), 30-40 barium hydroxide, iron powder-the rest [13]. In another patent, a flux-core wire with the filling factor of $16-20 \%$ was developed, with the composition, wt.\%: 70-80 iron carbonate, 17-23 barium hydroxide, and 3-7 alkaline silicate [14]. There is a wire with the composition, wt.\%: 20-30 barium peroxide; 20-50 iron oxide; 10-20 $\mathrm{K}_{2} \mathrm{Cr}_{2} \mathrm{O}_{7} ; 5-15$ aluminum; 5-40 Teflon [15]. Another wire with the filling factor of 25-30\% had the composition, wt.\%: 70-75 iron oxide; $21-24$ aluminum; 4-6 graphite [15].

A Chinese patent provides a wire with the composition, wt.\%: 40-60 aluminum and magnesium thermite, 10-35 marble, 5-10 potassium carbonate, 1-2 rare-earth element, 0-20 iron powder, $0-10$ nickel powder, $0-15$ potassium chlorate, and 5-10 hydroxymethylcellulose [16]. A $2 \mathrm{~mm}$ diameter wire was tested while cutting $8 \mathrm{~mm}$ thick Q235 steel at the current of 150-290 A, voltage 30-40 V. There is a flux-cored wire with the composition, wt. \%: 8-24 dolomite, $0.5-4$ quartz sand, $0.1-3$ cesium carbonate, $0.1-3$ potassium carbonate, $0.6-2.4$ cerium oxide, $2.4-4.8$ manganese peroxide, and calcium peroxide or barium peroxide - the rest [17]. Tests of a $2.2 \mathrm{~mm}$ diameter wire were conducted while cutting $20 \mathrm{~mm}$ thick Q235 steel at the current of 450-500 A, voltage of 45-50 V, and cutting speed of $200-230 \mathrm{~mm} / \mathrm{min}$.

In underwater wet cutting, the high stability of arc burning is important. For current and voltage studies, a $2 \mathrm{~mm}$ diameter oxidizing wire based on carbonates $\left(\mathrm{MgCO}_{3}, \mathrm{BaCO}_{3}\right)$ and peroxides $\left(\mathrm{BaO}_{2}, \mathrm{CaO}_{2}\right)$ and an exothermic wire with $75 \%$ termite mixture $(\mathrm{Al}+\mathrm{CuO})$ with the filling factor of 25-26\% were used [18]. An $8 \mathrm{~mm}$ thick Q235 steel was used for cutting at the wire feed rate of 8-17 m/min, current of 390-510 A, arc voltage of 35-40 V, and cutting speed of 270-300 mm/min. Deviation of the current reached $\pm 100-238 \mathrm{~A}$, and for voltage, $\pm 1.4-3.8 \mathrm{~V}$. Kerf width on the upper surface was 3.8-8.8 $\mathrm{mm}$ with a deviation of $\pm 1.2-1.9 \mathrm{~mm}$; on the lower surface, $6.1-12.1 \mathrm{~mm}$. According to the authors, the underwater 
wet cutting mechanism has four modes: normal arc, long arc, short arc, and exit of the wire from the kerf.

Underwater wet cutting of $6 \mathrm{~mm}$ thick steel with a $2 \mathrm{~mm}$ PPR-AN2 flux-cored wire was studied using a high-speed video camera at $2000 \mathrm{fps}$ at a current of $550 \mathrm{~A}$ and voltage of $25 \mathrm{~V}$ [19]. During cutting, there was periodic ignition and deepening the arc into the metal with slag formation. According to the authors, cutting has the modes: short circuit, arc development, and expansion of the vapor gas bubble, deepening the arc into the metal.

Cutting mechanism with a $2 \mathrm{~mm}$ diameter PPR-AN2 flux-cored wire was studied when cutting $16 \mathrm{~mm}$ thick Q235 steel in air and underwater [7,20]. The authors found four modes: arc burning inside the kerf, exit of the wire from the kef below the metal surface, short-circuiting of the wire against the edge of the metal, and re-ignition of the arc.

Temperature fields and the mechanism of underwater cutting of $16 \mathrm{~mm}$ thick Q235 steel were studied using an oxidizing flux-cored wire based on dolomite, cellulose, and peroxide [21]. The wire diameter was $2.2 \mathrm{~mm}$, the current strength was $350 \mathrm{~A}$, the voltage was $40 \mathrm{~V}$, the wire feed rate was $4.5 \mathrm{~m} / \mathrm{min}$, the cutting speed was $130 \mathrm{~mm} / \mathrm{min}$, and the kerf width was 8-11 $\mathrm{mm}$. Studies revealed the periodicity of arc ignition and breaking. However, no data on short circuits, duration of working, and idle cycles are available. According to the authors, cutting occurs at a constant arc length. However, this conclusion contradicts the oscillogram, according to which the current decreases and the voltage increases during cutting. These data indicate that the arc lengthens during cutting.

Parshin et al. [22] investigated metallurgical processes, but only in underwater welding. Parshin et al. [23] investigated electrical parameters in underwater cutting but without metallurgical processes. Parshin and Levchenko [24] also provided short information on underwater welding and cutting using flux-cored wire with the complex KOPS-M without a detailed study of metallurgical processes.

Therefore, the analysis of research on underwater wet cutting with a flux-cored wire shows that there is fragmentary information about the mechanism of cutting, arc properties, and slag formation. Detailed studies of metallurgical processes in the gas phase, ionized plasma, and slag are needed. This makes the research relevant.

The aim of the work was to study the mechanism and metallurgical processes of underwater wet cutting using flux-cored wires.

\section{Materials and Methods}

For underwater wet cutting, plates in size of $200 \mathrm{~mm} \times 100 \mathrm{~mm} \times 10 \mathrm{~mm}$ of $10 \mathrm{KhSND}$ low alloy steel according to GOST 19281-2014 (in Russian) or S355J0WP according to EN 10025-2:2004, wt.\%: 0.08C; 1Si; 0.6Mn; 0.8Ni; 0.8Cr; 0.1V; 0.5Cu, AISI 304L of $16 \mathrm{~mm}$ according to ASTM A240/A240M-20a, wt.\%: 0.01C;0.6Si; $1.8 \mathrm{Mn} ; 10 \mathrm{Ni} ; 18 \mathrm{Cr}, \mathrm{CuAl}$ aluminum bronze of $10 \mathrm{~mm}$ according to ISO 428:1983, wt.\%: $5 \mathrm{Al} ; 0.3 \mathrm{Fe} ; 0.7 \mathrm{Ni} ; 0.4 \mathrm{Mn}$; $0.3 \mathrm{Zn}$ and AlMg4.5Mn0.7 alloy of 6 and $12 \mathrm{~mm}$ according to EN AW-5083 were used. Underwater wet automatic cutting was carried out in a laboratory setup using flux-cored wires PPR-APL1 (UNTC "Svarka", St. Petersburg, Russia) with a diameter of $2 \mathrm{~mm}$ in accordance with ISO 12224-1 and GOST 26271-84 (in Russian), with the filling factor of $22 \%$, as shown in Figure 1. 


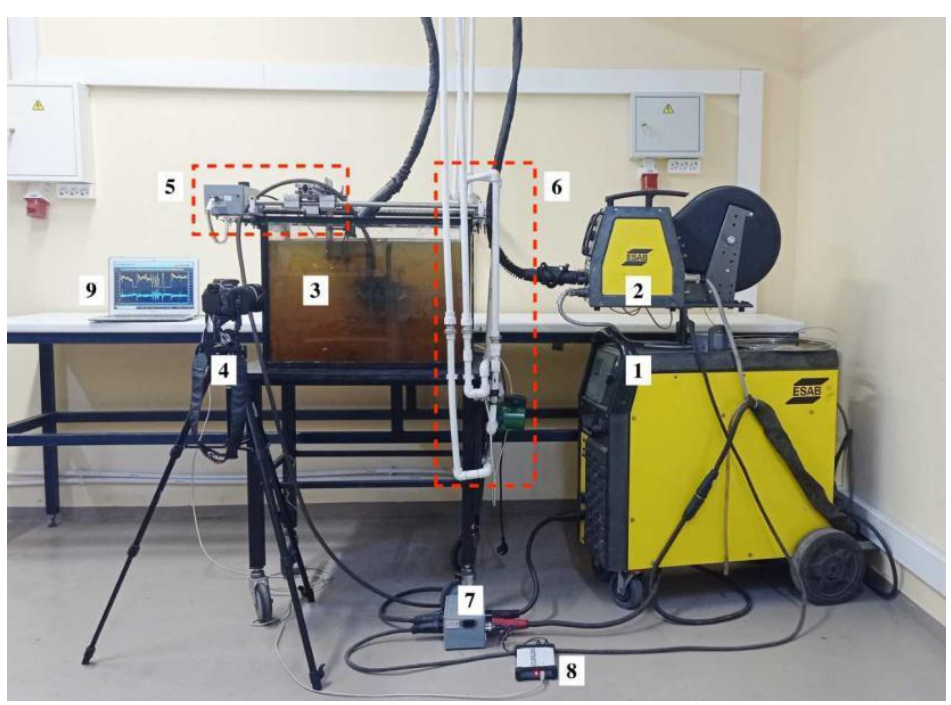

Figure 1. Underwater wet cutting setup: (1) source of power; (2) wire feed system; (3) water tank; (4) video camera; (5) automat of torch movement; (6) water supply system and pump; (7) welding current and arc voltage sensors; (8) USB-oscilloscope; (9) laptop.

For tests, we used 3 compositions of experimental flux-cored wires with different contents of the oxidizing mixture, as shown in Table 2.

Table 2. The composition of experimental flux-cored wires.

\begin{tabular}{ccccc}
\hline \multirow{2}{*}{ Wires } & \multicolumn{5}{c}{ Flux-Core Composition, wt. $\%$} \\
\cline { 2 - 5 } & $\mathbf{K N O}_{\mathbf{3}}$ & $\mathbf{F e C O}_{\mathbf{3}}$ & $\mathbf{N a}_{\mathbf{3}} \mathbf{A l F}_{\mathbf{6}}$ & $\mathbf{A l}$ \\
\hline PPR-APL1-1 & 30 & 30 & 20 & 20 \\
\hline PPR-APL1-2 & 25 & 25 & 20 & 30 \\
\hline PPR-APL1-3 & 35 & 35 & 20 & 10 \\
\hline
\end{tabular}

The power source was ESAB Origo MIG L405 with idling voltage $45 \mathrm{~V}$. The immersion depth of the samples in freshwater was $300 \mathrm{~mm}$. Underwater cutting parameters are shown in Table 3.

Table 3. Parameters of underwater wet cutting.

\begin{tabular}{|c|c|c|}
\hline Materials & Travel Speed, $\mathrm{mm} / \mathrm{min}$ & Wire Feed Rate, $\mathrm{m} / \mathrm{min}$ \\
\hline $\begin{array}{l}\text { 10KhSND of } 10 \mathrm{~mm} \\
\text { (3 plates) }\end{array}$ & $\begin{array}{c}50 \text { (1-4 tests); } 70 \text { (5-7 tests); } \\
100(8-10 \text { tests })\end{array}$ & $\begin{array}{c}7 ; 8 ; 9 ; 10(1-4 \text { tests }) ; 8 ; 9 ; 10 \\
(5-7 \text { tests }) ; 8 ; 9 ; 10(8-10 \text { tests })\end{array}$ \\
\hline $\begin{array}{l}\text { AISI 304L of } 16 \mathrm{~mm} \\
\text { (1 plate) }\end{array}$ & 70 (1-3 tests); 100 (4-6 tests) & $\begin{array}{c}8 ; 10 ; 12 \text { (1-3 tests); } 8 ; 10 ; 12 \\
\text { (4-6 tests) }\end{array}$ \\
\hline $\begin{array}{l}\mathrm{CuAl} 5 \text { of } 10 \mathrm{~mm} \\
\quad(1 \text { plate })\end{array}$ & 100 (1-3 tests) & $10 ; 12 ; 14$ (1-3 tests) \\
\hline $\begin{array}{l}\text { AlMg4.5Mn0.7 of } 6 \mathrm{~mm} \\
\text { (1 plate) }\end{array}$ & 200 & 5.5 \\
\hline $\begin{array}{l}\text { AlMg4.5Mn0.7 of } 12 \mathrm{~mm} \\
\text { (1 plate) }\end{array}$ & 150 & 5.7 \\
\hline
\end{tabular}

Arc voltage and current were measured using a digital USB oscilloscope and Multi VirAnalyzer 3.10.3.6 software (Harbin Instrustar Electronic Technology Co., Ltd., Harbin, China) at a frequency of $32 \mathrm{kHz}$. Analysis of electrical parameters from oscillograms was performed using the MATLAB program (The MathWorks, Inc., Natick, MA, USA). 
Research of the vapor gas bubble formation was performed by the shadow method with a laser system and Phantom VEO 710L high-speed camera (Vision Research, Wayne, NJ, USA) with a frequency of $8000 \mathrm{~Hz}$. Phantom CV 2.7.756.2 software (Vision Research Inc., Wayne, NJ, USA) was used for image visualization and analysis. For thermodynamic modeling of the chemical reactions, the plasma thermophysical properties and the phase composition of plasma and slag used the IVTANTHERMO 2001 software (Joint Institute for High Temperatures of the Russian Academy of Sciences, Moscow, Russia) and FactSage 8.1 software (CRCT, Montreal, QC, Canada).

\section{Research Results}

\subsection{Mechanism of Underwater Wet Cutting}

Underwater cutting, as with welding, takes place in a vapor gas bubble atmosphere, as shown in Figure 2.

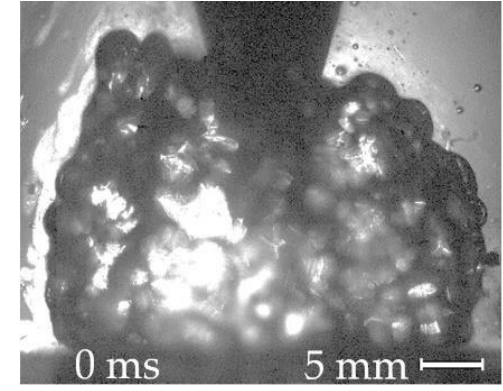

(a)

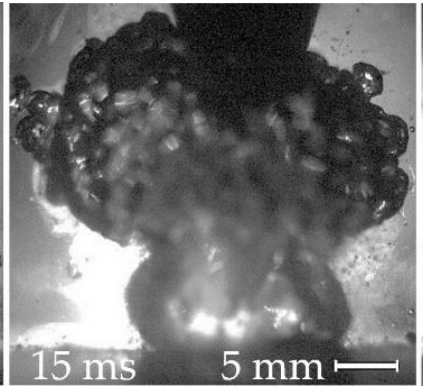

(b)

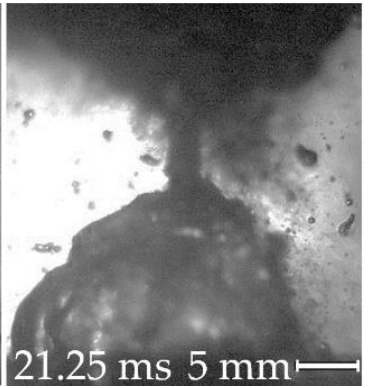

(c)

Figure 2. Dynamics of the vapor gas bubble during underwater wet cutting using flux-cored wire: (a) arc deepening in the metal, vapor gas bubble stabilization; (b) vapor gas bubble collapse and new bubble formation; (c) old bubble detachment, new bubble expansion.

The peculiarity of underwater wet cutting is that when the components decompose, oxygen is produced, which oxidizes the iron and forms slag. The slag is then forced out of the cutting zone under arc pressure. Another feature is the presence of periodic working and idle cycles in the electrical process. These cycles are associated with periodic ignition and breaking of the electric arc during the formation of a through kerf, as shown in Figure 3.

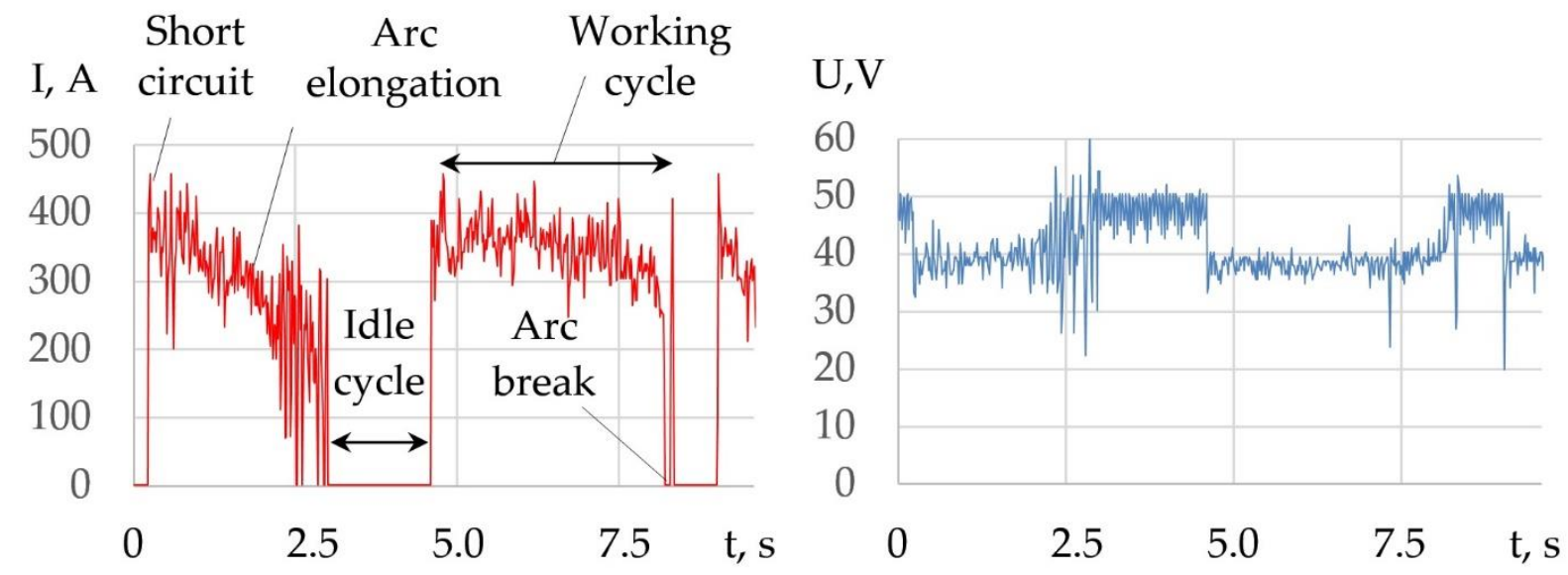

Figure 3. Typical oscillogram of current and voltage during underwater cutting with a $2 \mathrm{~mm}$ diameter PPR-APL1 flux-cored wire.

The working cycle of cutting includes the physical phenomena: short-circuit, arc elongation, and arc break. The idle cycle is the pause between arc break and short-circuit. Depending on the cutting mode and composition of the flux-cored wire, the duration of 
working cycles is $1.5-5 \mathrm{~s}$, and idle cycles is $0.6-1.7 \mathrm{~s}$. The mechanism of the underwater wet cutting process consists of five phases, as shown in Figure 4.

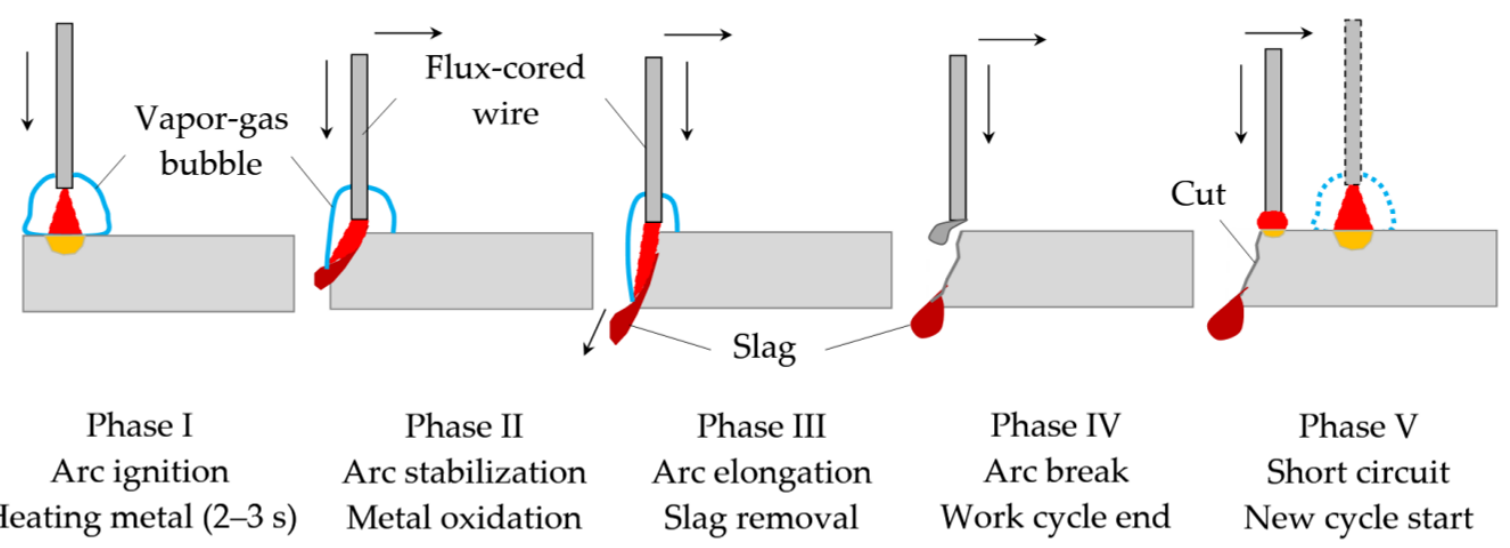

Figure 4. Mechanism of underwater wet cutting using flux-cored wires.

The mechanism of underwater wet cutting has five phases: arc starting, metal heating, vapor gas bubble formation; arc stabilization, beginning of metal oxidation, vapor gas bubble expansion; arc elongation, slag removal, vapor gas bubble collapse; arc breaking with the formation of a through kerf, idle cycle; short circuit and the start of a new working cycle. The cutting process begins with phase I starting the arc, forming a vapor gas bubble, and heating the metal to initiate the oxidation reaction. Stabilization of the arc and development of the oxidation reaction in phase II leads to elongation of the arc as the arc deepens into the kerf, increasing arc voltage and slag formation. In phase III, there is a further increase in arc voltage and arc length, a decrease in the current, formation of a through kerf, and removal of slag by arc pressure. At the point of formation of the through kerf, the arc breaks, and the working cycle ends in phase III. The pause between phases IV and V is an idle cycle in which there is zero current and voltage equals the output voltage of the power supply. A short circuit at the cutting edge begins a new working cycle in phase $\mathrm{V}$.

Underwater wet cutting is similar to welding because it takes place in a vapor gas bubble with an intense decomposition of water and flux-cored wire components. However, unlike welding, the cutting process takes place in a narrow kerf that stabilizes arc burning and the process of plasma ionization in the oxidizing gas mixture, as shown in Figure 5.

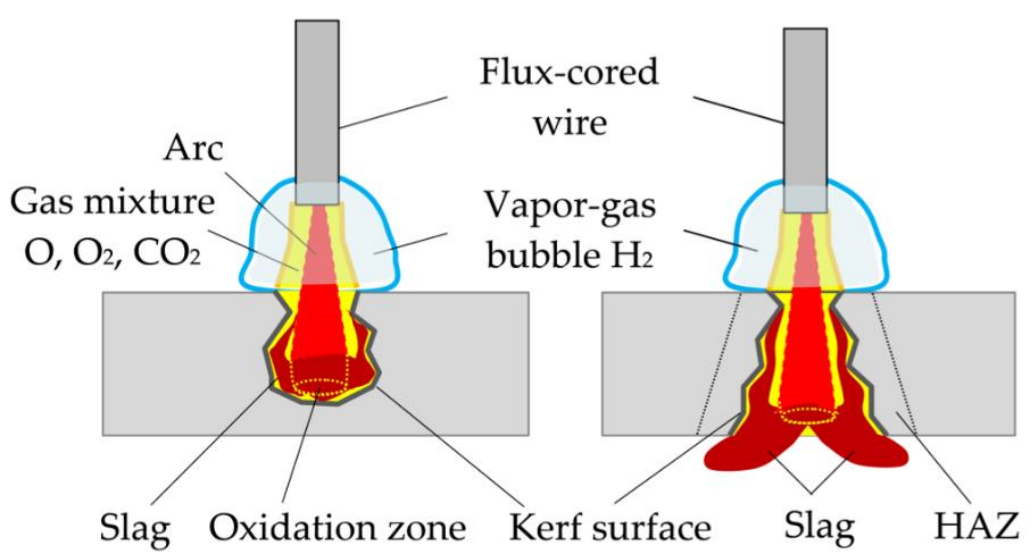

(a)

(b)

Figure 5. Model of arc penetration and stabilization during underwater wet arc cutting using a flux-cored wire in the cross-section: (a) closed kerf; (b) open kerf. (HAZ) Heat-affected zone. 


\subsection{Dissociation of Components and Oxidation of Iron}

The formation of an oxidizing atmosphere around the arc is a prerequisite for underwater cutting. The composition of the oxidizing atmosphere is determined by the dissociation of the components of the flux-cored wire. Alkali metal and iron carbonates, as well as sodium and potassium nitrates, are used as basic components. In endothermic Reactions (1)-(7), dissociation of salts and formation of $\mathrm{CO}_{2}, \mathrm{O}_{2}$, and $\mathrm{NO}$ occurs, as shown in Figure 6:

$$
\begin{aligned}
& \mathrm{Na}_{2} \mathrm{CO}_{3}=\mathrm{Na}_{2} \mathrm{O}+\mathrm{CO}_{2}-\mathrm{Q} \\
& \mathrm{K}_{2} \mathrm{CO}_{3}=\mathrm{K}_{2} \mathrm{O}+\mathrm{CO}_{2}-\mathrm{Q} \\
& \mathrm{Li}_{2} \mathrm{CO}_{3}=\mathrm{Li}_{2} \mathrm{O}+\mathrm{CO}_{2}-\mathrm{Q} \\
& \mathrm{Cs}_{2} \mathrm{CO}_{3}=\mathrm{Cs}_{2} \mathrm{O}+\mathrm{CO}_{2}-\mathrm{Q} \\
& \mathrm{FeCO}_{3}=\mathrm{FeO}+\mathrm{CO}_{2}-\mathrm{Q} \\
& \mathrm{NaNO}_{3}=0.5 \mathrm{Na}_{2} \mathrm{O}+\mathrm{NO}+0.5 \mathrm{O}_{2}-\mathrm{Q} \\
& \mathrm{KNO}_{3}=0.5 \mathrm{~K}_{2} \mathrm{O}+\mathrm{NO}+0.5 \mathrm{O}_{2}-\mathrm{Q}
\end{aligned}
$$
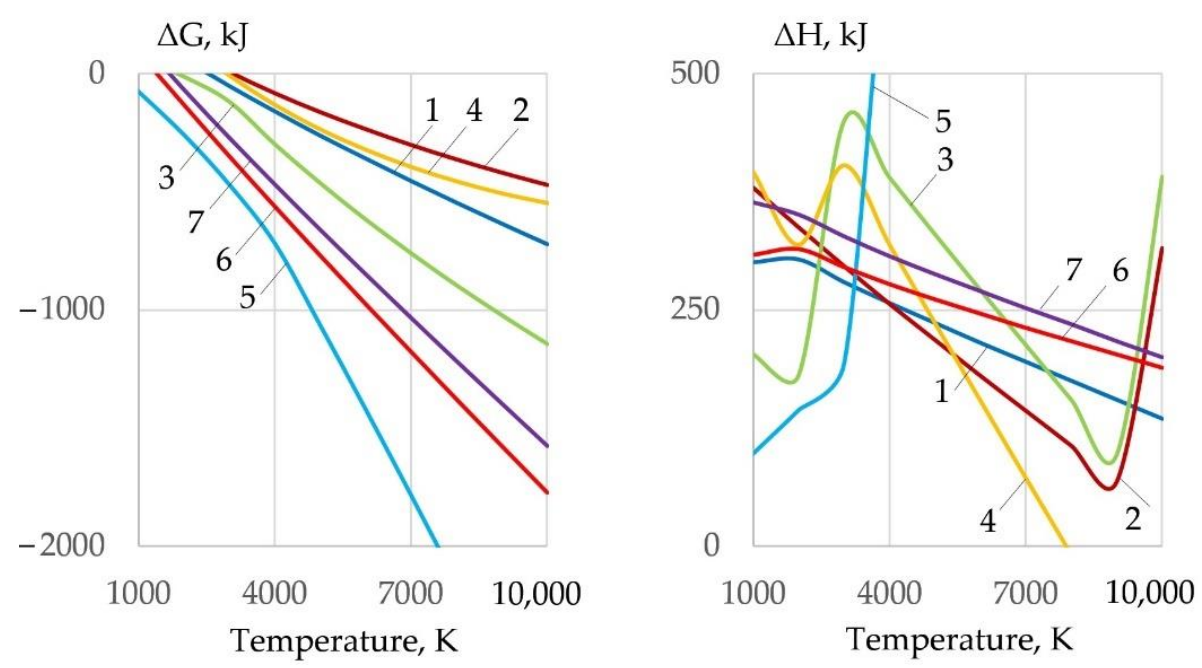

Figure 6. Change of Gibbs free energy and enthalpy of salt dissociation reactions (1)-(7).

Dissociation reactions require energy, so the change in enthalpy of Reactions (1)-(7) has a positive value. Particularly, active dissociation occurs in $\mathrm{FeCO}_{3}, \mathrm{NaNO}_{3}, \mathrm{KNO}_{3}$, and $\mathrm{Li}_{2} \mathrm{CO}_{3}$ salts, of which $\mathrm{FeCO}_{3}$ and $\mathrm{Li}_{2} \mathrm{CO}_{3}$ have minimum $\Delta \mathrm{H}$ values at $1000-3000 \mathrm{~K}$. Formation of oxidizing atmosphere during cutting leads to oxidation of $\mathrm{Fe}, \mathrm{Cr}$, $\mathrm{Ni}$ by Reactions (8)-(14):

$$
\begin{gathered}
\mathrm{Fe}+\mathrm{O}=\mathrm{FeO}+\mathrm{Q} \\
\mathrm{Fe}+0.5 \mathrm{O}_{2}=\mathrm{FeO}+\mathrm{Q} \\
\mathrm{Fe}+\mathrm{CO}=\mathrm{FeO}+\mathrm{C} \pm \mathrm{Q} \\
\mathrm{Fe}+\mathrm{CO}_{2}=\mathrm{FeO}+\mathrm{CO}-\mathrm{Q} \\
\mathrm{Fe}+\mathrm{NO}=\mathrm{FeO}+0.5 \mathrm{~N}_{2}+\mathrm{Q} \\
\mathrm{Cr}+1.5 \mathrm{O}=0.5 \mathrm{Cr}_{2} \mathrm{O}_{3}+\mathrm{Q} \\
\mathrm{Ni}+\mathrm{O}=\mathrm{NiO}+\mathrm{Q}
\end{gathered}
$$

At the temperature of $1000-4000 \mathrm{~K}$, iron oxidation reactions are possible (15)-(21) when interacting with salts, especially with $\mathrm{FeCO}_{3}, \mathrm{NaNO}_{3}, \mathrm{KNO}_{3}$ :

$$
\mathrm{Na}_{2} \mathrm{CO}_{3}+\mathrm{Fe}=\mathrm{FeO}+\mathrm{Na}_{2} \mathrm{O}+\mathrm{CO}
$$




$$
\begin{gathered}
\mathrm{K}_{2} \mathrm{CO}_{3}+\mathrm{Fe}=\mathrm{FeO}+\mathrm{K}_{2} \mathrm{O}+\mathrm{CO} \\
\mathrm{Li}_{2} \mathrm{CO}_{3}+\mathrm{Fe}=\mathrm{FeO}+\mathrm{Li}_{2} \mathrm{O}+\mathrm{CO} \\
\mathrm{Cs}_{2} \mathrm{CO}_{3}+\mathrm{Fe}=\mathrm{FeO}+\mathrm{Cs}_{2} \mathrm{O}+\mathrm{CO} \\
\mathrm{FeCO}_{3}+\mathrm{Fe}=\mathrm{FeO}+\mathrm{CO}_{2} \\
\mathrm{NaNO}_{3}+\mathrm{Fe}=0.5 \mathrm{Fe}_{2} \mathrm{O}_{3}+0.5 \mathrm{Na}_{2} \mathrm{O}+\mathrm{NO} \\
\mathrm{KNO}_{3}+\mathrm{Fe}=0.5 \mathrm{Fe}_{2} \mathrm{O}_{3}+0.5 \mathrm{~K}_{2} \mathrm{O}+\mathrm{NO}
\end{gathered}
$$

In the oxidation reactions of $\mathrm{Fe}, \mathrm{Cr}$, and $\mathrm{Ni}$, the most active components are $\mathrm{O}, \mathrm{O}_{2}$, $\mathrm{CO}_{2}$, and NO. Unlike dissociation reactions, oxidation reactions release heat, i.e., reduce the internal energy of the gas system, as shown in Figure 7.
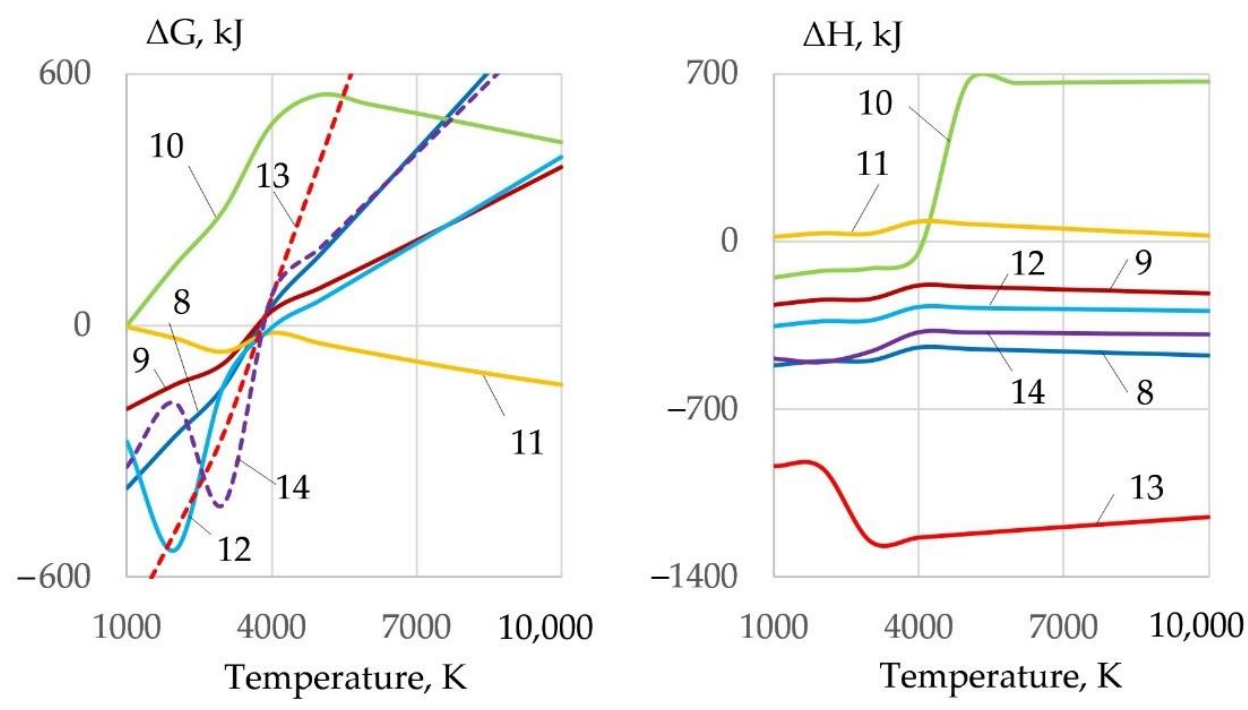

$\Delta \mathrm{G}, \mathrm{kJ}$
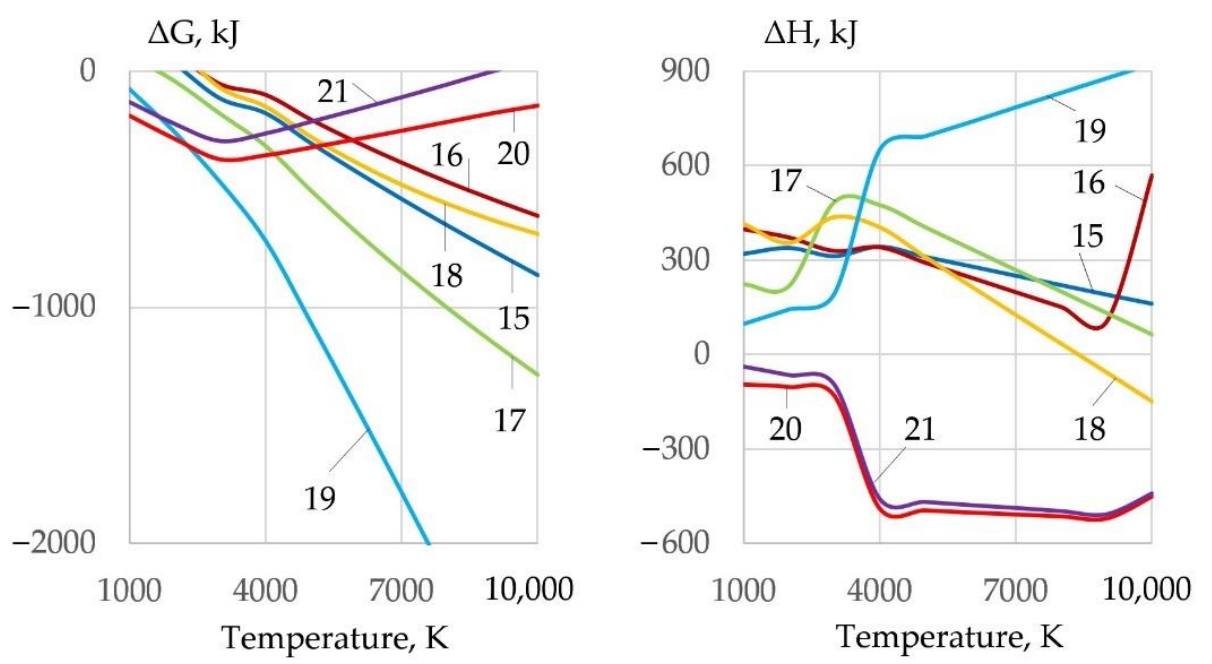

Figure 7. Change of Gibbs free energy and enthalpy of iron oxidation reactions (8)-(21) in interaction with gases and salts.

Dissociation of salts leads to the formation of a complex mixture of gases $\mathrm{O}, \mathrm{O}_{2}, \mathrm{CO}$, $\mathrm{CO}_{2}$, and NO, as shown in Figure 8. 


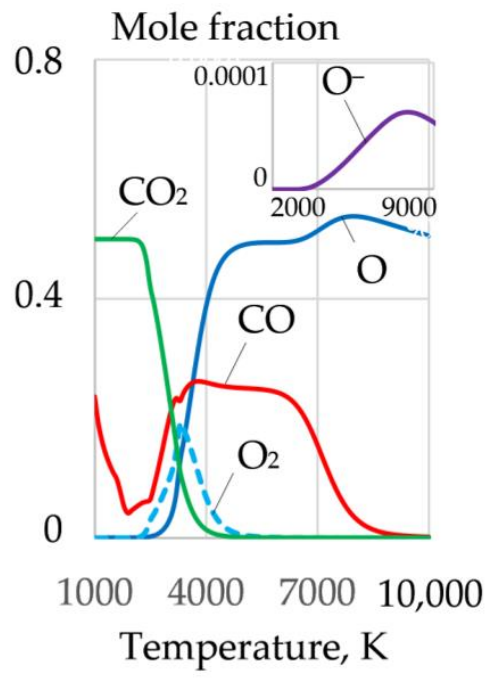

(a)

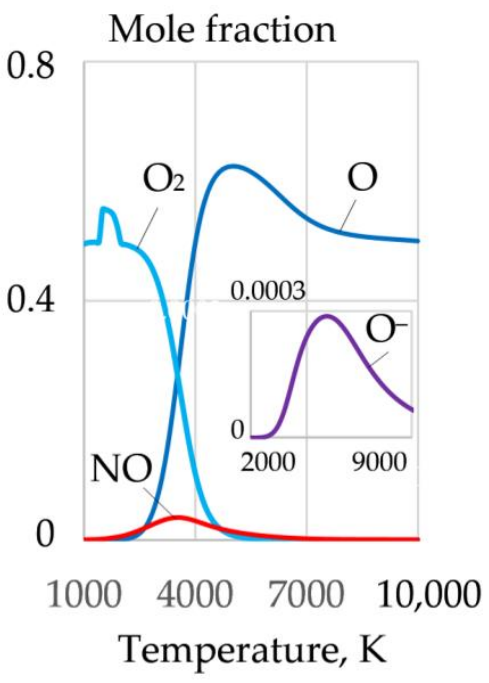

(b)

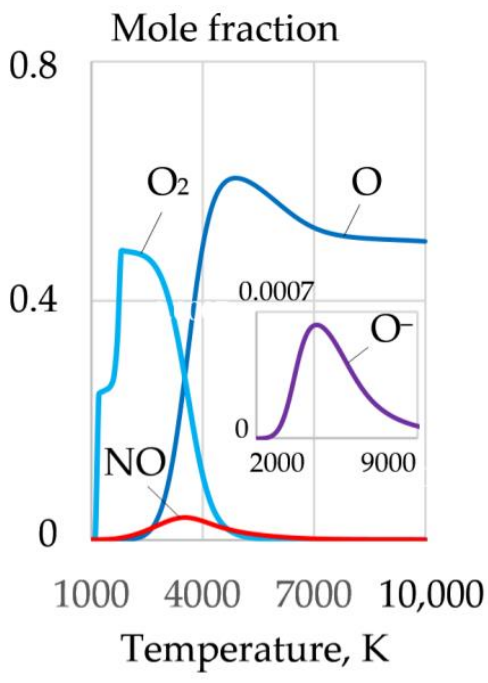

(c)

Figure 8. Mole fractions of gases and negative ions of oxygen $\mathrm{O}^{-}$during dissociation of salts: (a) $\mathrm{FeCO}_{3} ;(\mathbf{b}) \mathrm{NaNO}_{3}$; (c) $\mathrm{KNO}_{3}$.

The greatest amount of molecular and atomic oxygen is produced during the dissociation of sodium and potassium nitrate. However, a high concentration of these salts reduces the arc stability because of the formation of negative ions of atomic and molecular oxygen ${ }^{-}$, at the arc boundary. A mixture of $\mathrm{FeCO}_{3}$ and $\mathrm{KNO}_{3}$ can be used to improve arc stability. Such a mixture provides high oxygen content and low concentration of atomic oxygen $\left(\mathrm{O}^{-}\right)$, as shown in Figures 9 and 10.

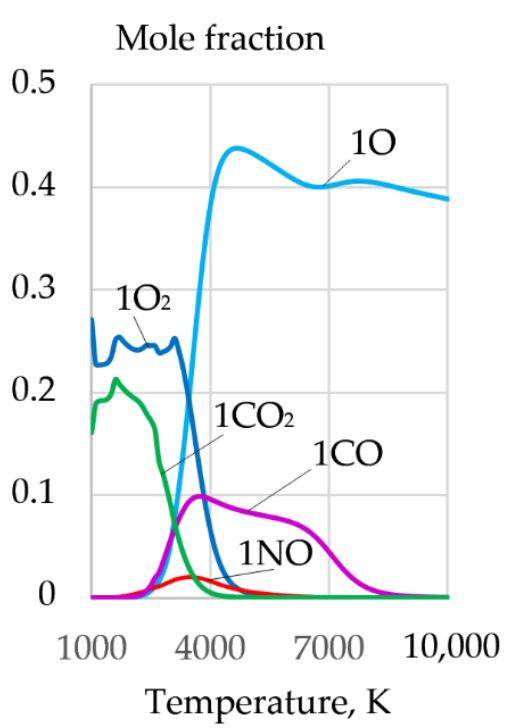

(a)

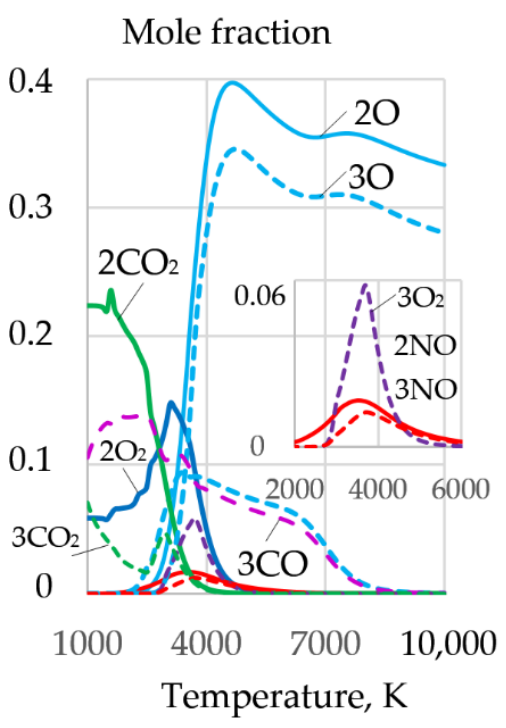

(b)

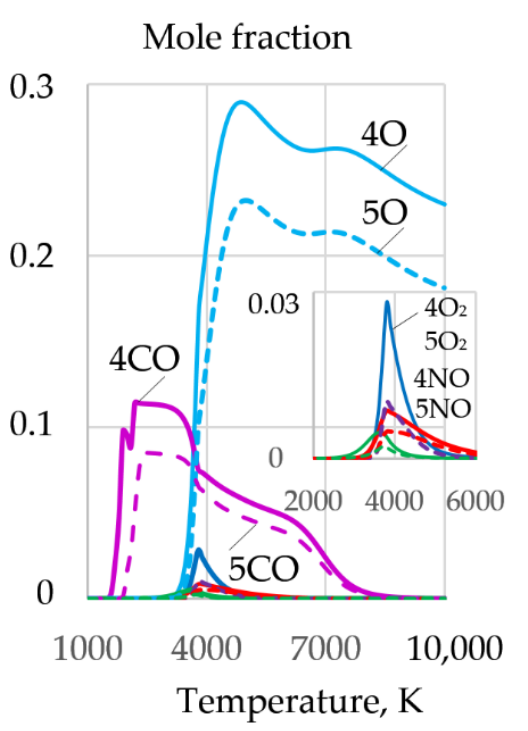

(c)

Figure 9. Mole fractions of gases in the system, wt.\%: (a): (1) $40 \mathrm{FeCO}_{3}+40 \mathrm{KNO}_{3}+20 \mathrm{Na}_{3} \mathrm{AlF}_{6}$; (b): (2) $35 \mathrm{FeCO}_{3}+$ $35 \mathrm{KNO}_{3}+20 \mathrm{Na}_{3} \mathrm{AlF}_{6}+10 \mathrm{Al} ;(3) 30 \mathrm{FeCO}_{3}+30 \mathrm{KNO}_{3}+20 \mathrm{Na}_{3} \mathrm{AlF}_{6}+20 \mathrm{Al} ;$ (c): (4) $25 \mathrm{FeCO}_{3}+25 \mathrm{KNO}_{3}+20 \mathrm{Na}_{3} \mathrm{AlF}_{6}+30 \mathrm{Al}$; (5) $20 \mathrm{FeCO}_{3}+20 \mathrm{KNO}_{3}+20 \mathrm{Na}_{3} \mathrm{AlF}_{6}+40 \mathrm{Al}$.

\subsection{Ionization and Thermophysical Properties of Plasma}

During cutting, periodic short circuits, breaks, and ignitions of the arc occur. Therefore, the arc plasma should have a high concentration of electrons. Aluminum with low ionization energy $-577.6 \mathrm{~kJ} / \mathrm{mol}$ - can be introduced to improve ionization. As the aluminum 
content increases, the concentration of electrons increases, and the concentration of $\mathrm{F}^{-}, \mathrm{O}^{-}$ ions decreases, as shown in Figure 10.

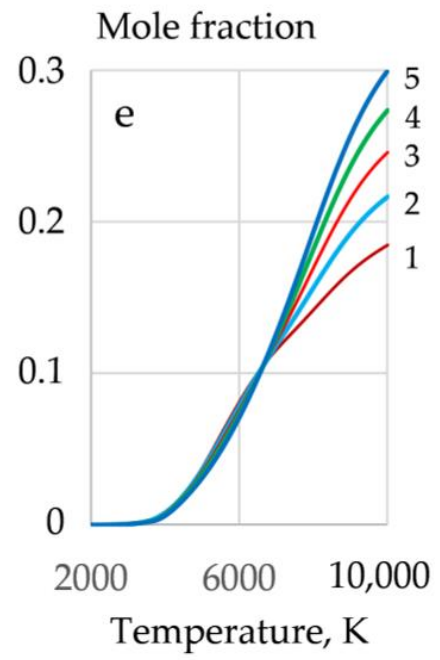

(a)

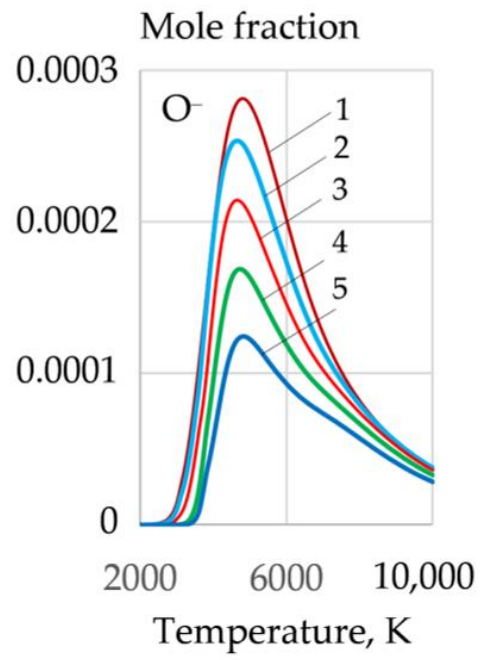

(b)

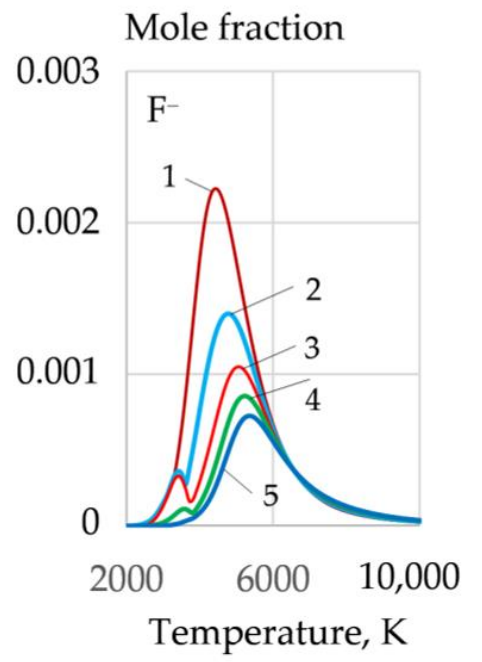

(c)

Figure 10. Mole fractions of electrons (a), negative ions of atomic oxygen (b), and negative ions of fluorine (c) in the equilibrium gas system, wt. $\%$ : (1) $40 \mathrm{FeCO}_{3}+40 \mathrm{KNO}_{3}+20 \mathrm{Na}_{3} \mathrm{AlF}_{6}$; (2) $35 \mathrm{FeCO}_{3}+35 \mathrm{KNO}_{3}+20 \mathrm{Na}_{3} \mathrm{AlF}_{6}+10 \mathrm{Al} ;$ (3) $30 \mathrm{FeCO} 3+$ $30 \mathrm{KNO}_{3}+20 \mathrm{Na}_{3} \mathrm{AlF}_{6}+20 \mathrm{Al} ;(4) 25 \mathrm{FeCO}_{3}+25 \mathrm{KNO}_{3}+20 \mathrm{Na}_{3} \mathrm{AlF}_{6}+30 \mathrm{Al} ;(5) 20 \mathrm{FeCO}_{3}+20 \mathrm{KNO}_{3}+20 \mathrm{Na}_{3} \mathrm{AlF} 6+40 \mathrm{Al}$

Dissociation of the components causes an increase in the thermal conductivity, heat capacity, and enthalpy of the gas system, and a decrease in dynamic viscosity in the dissociation temperature range of 1000-4000 K, as shown in Figure 11.

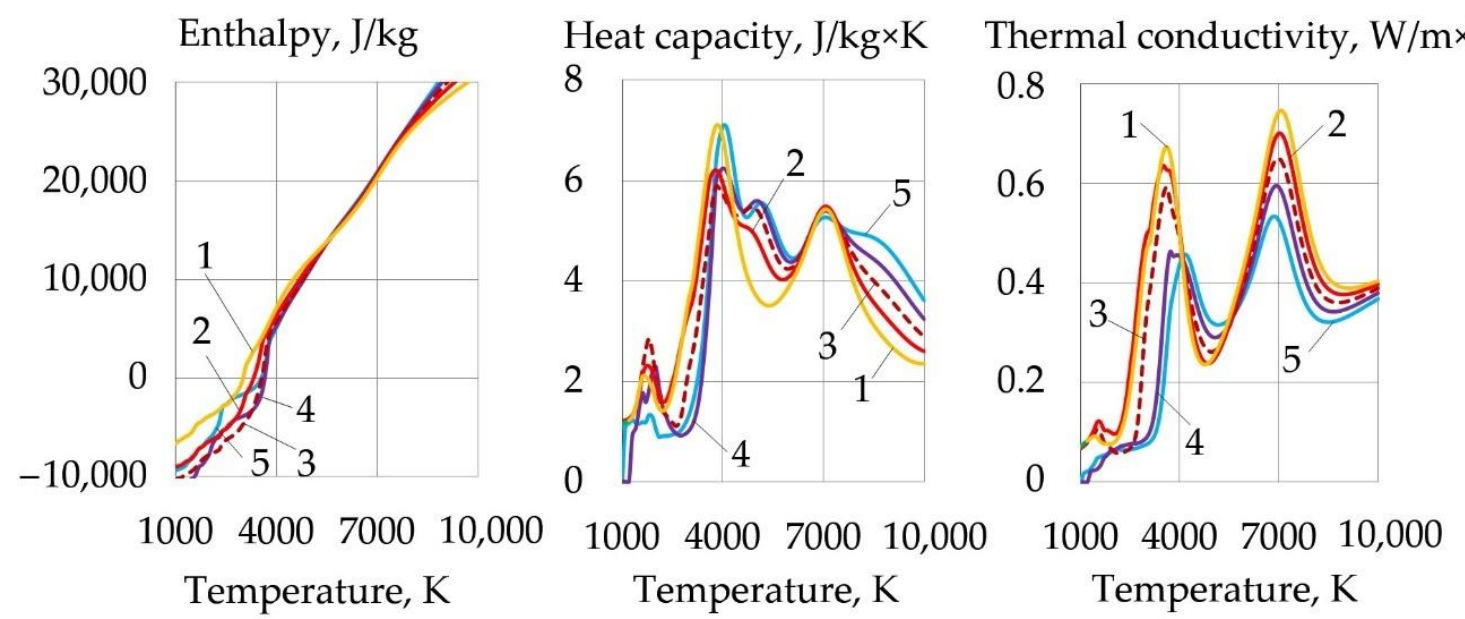

Figure 11. Thermophysical properties of plasma for component mixtures, wt. $\%$ : (1) $40 \mathrm{FeCO}_{3}+40 \mathrm{KNO}_{3}+20 \mathrm{Na}_{3} \mathrm{AlF}_{6}$; (2) $35 \mathrm{FeCO}_{3}+35 \mathrm{KNO}_{3}+20 \mathrm{Na}_{3} \mathrm{AlF}_{6}+10 \mathrm{Al}$; (3) $30 \mathrm{FeCO}_{3}+30 \mathrm{KNO}_{3}+20 \mathrm{Na}_{3} \mathrm{AlF}_{6}+20 \mathrm{Al}$; (4) $25 \mathrm{FeCO}_{3}+25 \mathrm{KNO}_{3}+$ $20 \mathrm{Na}_{3} \mathrm{AlF}_{6}+30 \mathrm{Al} ;(5) 20 \mathrm{FeCO}_{3}+20 \mathrm{KNO}_{3}+20 \mathrm{Na}_{3} \mathrm{AlF}_{6}+40 \mathrm{Al}$.

As the temperature and salt concentration increase, the enthalpy, heat capacity, and thermal conductivity of the plasma increase. The thermophysical properties of the plasma in the temperature range of $1000-4000 \mathrm{~K}$, in which oxidation reactions have a negative Gibbs free energy, are important for efficient cutting. Increasing the aluminum concentration leads to a slight decrease in enthalpy, heat capacity, and thermal conductivity. The introduction of $\mathrm{FeCO}_{3}$ together with $\mathrm{KNO}_{3}$ allowed increasing the thermal conductivity of the plasma from 0.59 to $0.67 \mathrm{~W} / \mathrm{m} \cdot \mathrm{K}$ at $3600 \mathrm{~K}$ compared to pure $\mathrm{KNO}_{3}$. 


\subsection{Exothermic Effect}

The exothermic effect with the addition of aluminum improves the stability and increases the weld penetration in underwater wet welding [25]. Underwater wet cutting has significant energy consumption for water and component dissociation, plasma ionization, maintaining stable vapor gas bubble dynamics, and compensating for heat loss as the metal cools in the water.

The arc is a complex self-regulating system according to the principles of Le Chatelier and Steinbeck. To compensate energy loss, the arc increases voltage and power, which reaches $10-20 \mathrm{~kW}$ during cutting. Increasing the voltage is also necessary to improve plasma ionization as the arc lengthens in the kerf. The maximum arc length when cutting with a $2 \mathrm{~mm}$ flux-cored wire reaches up to $20-25 \mathrm{~mm}$, which is 10 times the length of the welding arc in the air.

Energy loss and arc elongation require improvement of ionization and thermophysical properties of plasma. Therefore, the gas system must have maximum enthalpy, heat capacity, and thermal conductivity. Heat release in exothermic reactions changes the thermophysical properties of the gas phase. The most efficient oxides for exothermic Reactions (22)-(28) with aluminum are $\mathrm{Fe}_{3} \mathrm{O}_{4}, \mathrm{MoO}_{2}$, and $\mathrm{WO}_{2}$, as shown in Figure 12:

$$
\begin{gathered}
1.5 \mathrm{Fe}_{3} \mathrm{O}_{4}+4 \mathrm{Al}=2 \mathrm{Al}_{2} \mathrm{O}_{3}+4.5 \mathrm{Fe}+\mathrm{Q} \\
0.5 \mathrm{Fe}_{2} \mathrm{O}_{3}+\mathrm{Al}=0.5 \mathrm{Al}_{2} \mathrm{O}_{3}+\mathrm{Fe}+\mathrm{Q} \\
1.5 \mathrm{FeO}+\mathrm{Al}=0.5 \mathrm{Al}_{2} \mathrm{O}_{3}+1.5 \mathrm{Fe}+\mathrm{Q} \\
0.5 \mathrm{Fe}_{3} \mathrm{O}_{4}+2 \mathrm{Mg}=2 \mathrm{MgO}+1.5 \mathrm{Fe}+\mathrm{Q} \\
0.5 \mathrm{Fe}_{3} \mathrm{O}_{4}+\mathrm{Ti}=\mathrm{TiO}_{2}+1.5 \mathrm{Fe}+\mathrm{Q} \\
1.5 \mathrm{MoO}_{2}+2 \mathrm{Al}=\mathrm{Al}_{2} \mathrm{O}_{3}+1.5 \mathrm{Mo}+\mathrm{Q} \\
1.5 \mathrm{WO}_{2}+2 \mathrm{Al}=\mathrm{Al}_{2} \mathrm{O}_{3}+1.5 \mathrm{~W}+\mathrm{Q}
\end{gathered}
$$

$\Delta \mathrm{G}, \mathrm{kJ}$

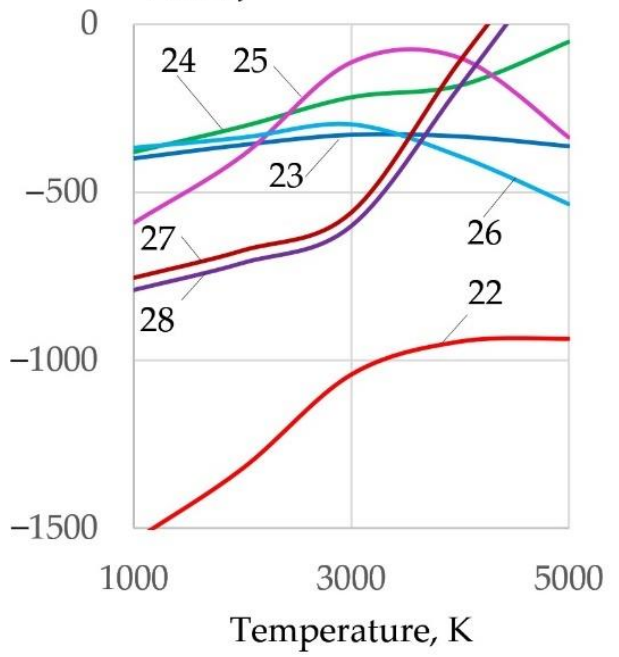

$\Delta \mathrm{H}, \mathrm{kJ}$

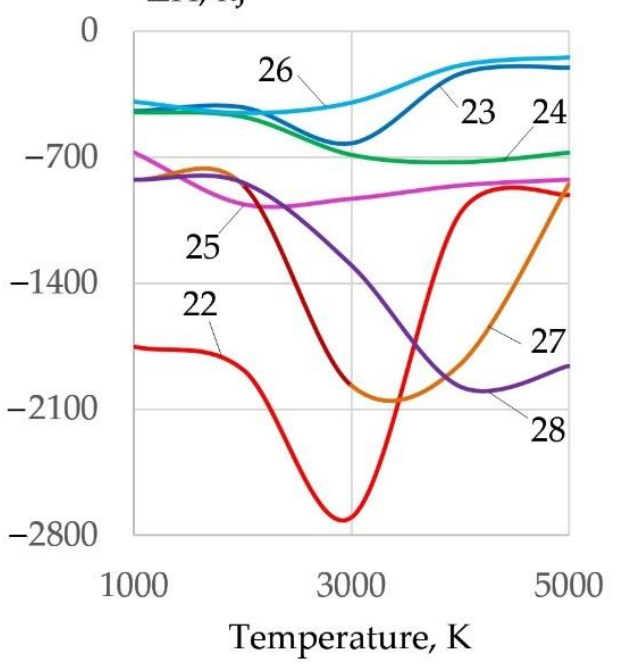

Figure 12. Change of Gibbs free energy and the enthalpy of deoxidation reactions during interaction of oxides with aluminum.

The use of an exothermic mixture compared to an oxidizing mixture improves plasma ionization and reduces the concentration of negative $\mathrm{F}^{-}, \mathrm{O}^{-}$ions, as shown in Figure 13. 


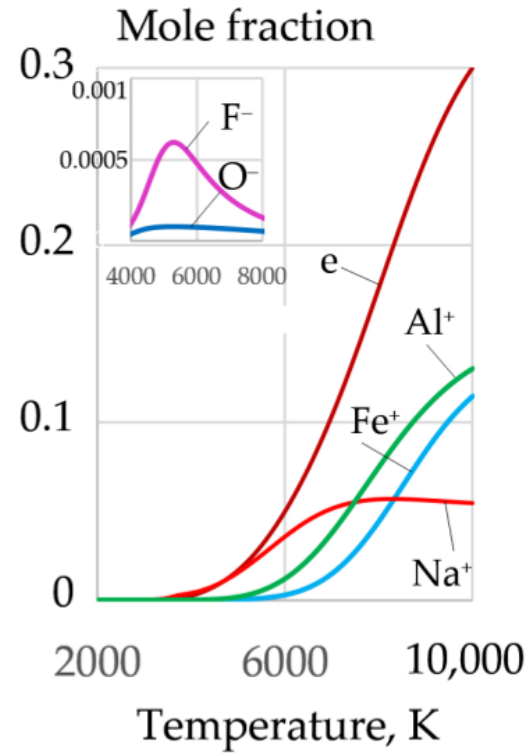

(a)

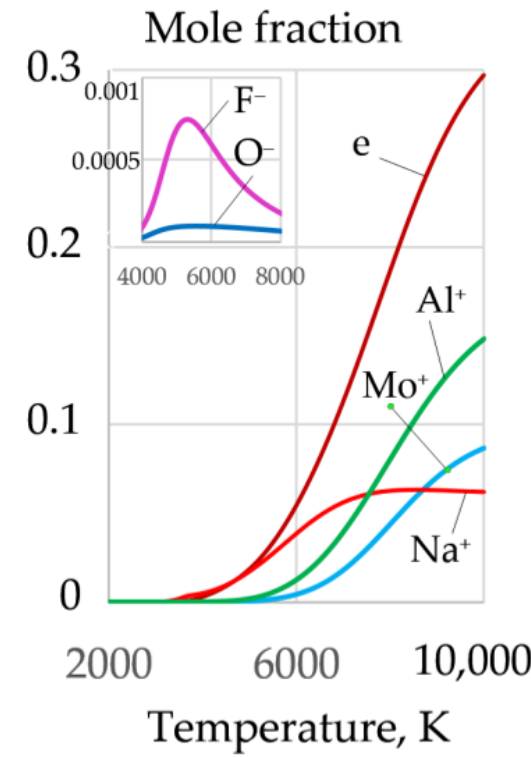

(b)

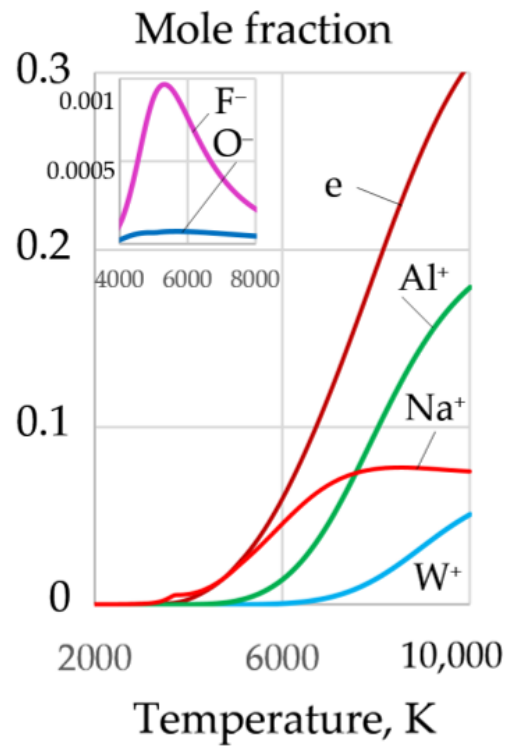

(c)

Figure 13. Mole fractions of electrons and ions in the system, wt. $\%$ : (a) $60 \mathrm{Fe}_{3} \mathrm{O}_{4}+20 \mathrm{Al}+20 \mathrm{Na}_{3} \mathrm{AlF}_{6} ;(\mathbf{b}) 60 \mathrm{MoO} 2+20 \mathrm{Al}+$ $20 \mathrm{Na}_{3} \mathrm{AlF}_{6} ;$ (c) $60 \mathrm{WO}_{2}+20 \mathrm{Al}+20 \mathrm{Na}_{3} \mathrm{AlF}_{6}$.

However, the enthalpy, heat capacity, and thermal conductivity are reduced compared to the oxidizing mixture, wt. $\%: 30 \mathrm{FeCO}_{3}+30 \mathrm{KNO}_{3}+20 \mathrm{Na}_{3} \mathrm{AlF}_{6}+20 \mathrm{Al}$, as shown in Figures 11 and 14.
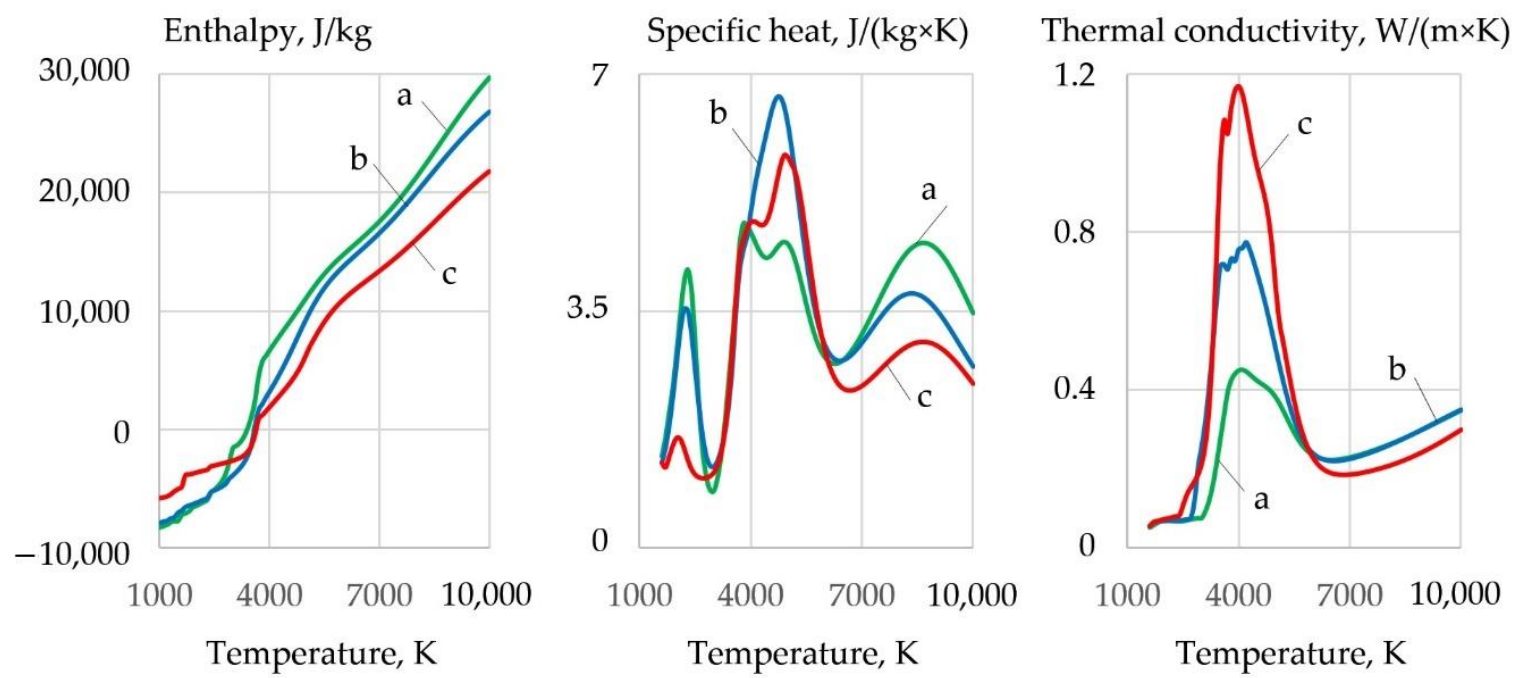

Figure 14. Thermophysical properties of the system, wt. $\%$ : (a) $60 \mathrm{Fe}_{3} \mathrm{O}_{4}+20 \mathrm{Al}+20 \mathrm{Na}_{3} \mathrm{AlF}_{6}$; (b) $60 \mathrm{MoO} 2+20 \mathrm{Al}+$ $20 \mathrm{Na}_{3} \mathrm{AlF}_{6} ;\left(\right.$ c) $60 \mathrm{WO}_{2}+20 \mathrm{Al}+20 \mathrm{Na}_{3} \mathrm{AlF}_{6}$.

\subsection{Formation of Oxides and Slag}

Underwater wet cutting can be used for various steels and alloys that contain the elements $\mathrm{Fe}, \mathrm{Si}, \mathrm{Mn}, \mathrm{Cr}, \mathrm{Ni}, \mathrm{Cu}, \mathrm{Al}$, and Ti. When the metal is oxidized, a refractory slag is formed that hinders the cutting process, as shown in Figure 15. 


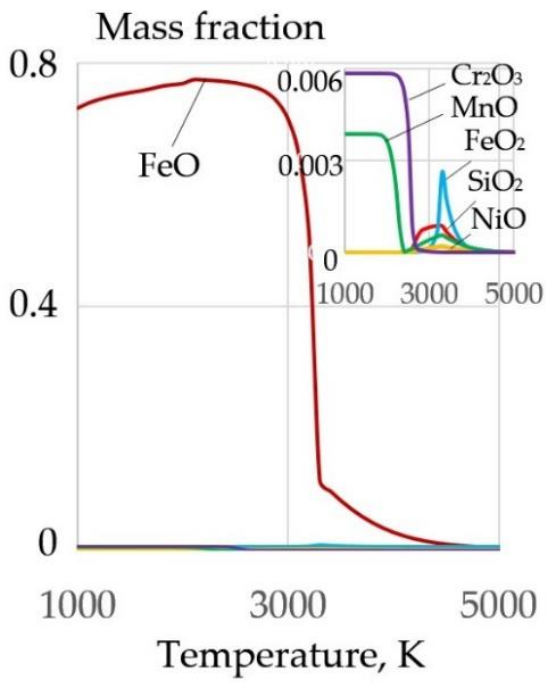

(a)

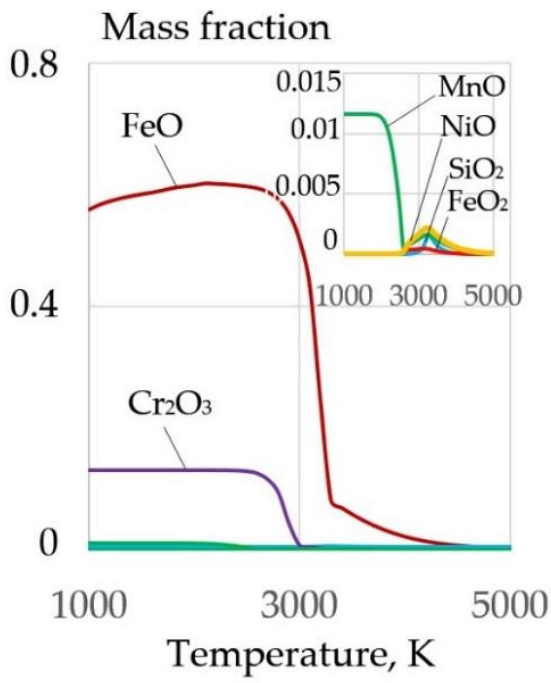

(b)

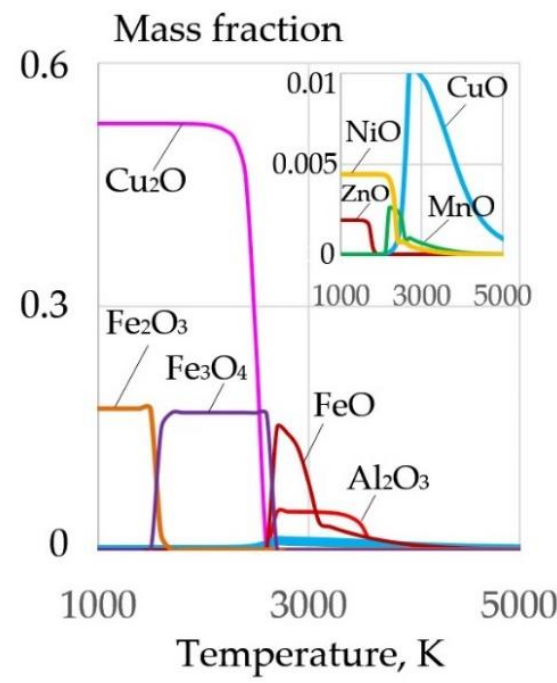

(c)

Figure 15. Mass fractions of oxides in the equilibrium system, wt.\%: (a) $25 \mathrm{FeCO}_{3}-25 \mathrm{KNO}_{3}-50(10 \mathrm{KhSND})$ steel; (b) $25 \mathrm{FeCO}{ }^{-}$ $25 \mathrm{KNO}_{3}-50$ (AISI 304L) steel; (c) $25 \mathrm{FeCO}_{3}-25 \mathrm{KNO}_{3}-50\left(\mathrm{CuAl}_{5}\right)$ alloy.

The slag is removed from the cutting zone under the influence of the balance of forces: gravitational force, arc pressure force, and surface tension force. To remove the slag, it is necessary to reduce its surface tension, which can be achieved by ionic dissolution of oxides in $\mathrm{Na}_{3} \mathrm{AlF}_{6}$ cryolite. At high temperatures (in the arc zone), interaction of slag oxides with cryolite is possible by Reactions (29)-(34), as shown in Figure 16:

$$
\begin{gathered}
1.5 \mathrm{FeO}+\mathrm{Na}_{3} \mathrm{AlF}_{6}=1.5 \mathrm{FeF}_{2}+1.5 \mathrm{Na}_{2} \mathrm{O}+\mathrm{AlF}_{3} \\
0.5 \mathrm{Fe}_{2} \mathrm{O}_{3}+\mathrm{Na}_{3} \mathrm{AlF}_{6}=\mathrm{FeF}_{3}+1.5 \mathrm{Na}_{2} \mathrm{O}+\mathrm{AlF}_{3} \\
0.5 \mathrm{Fe}_{3} \mathrm{O}_{4}+\mathrm{Na}_{3} \mathrm{AlF}_{6}=1.5 \mathrm{FeF}_{2}+1.5 \mathrm{Na}_{2} \mathrm{O}+\mathrm{AlF}_{3}+0.5 \mathrm{O}_{2} \\
0.5 \mathrm{Cr}_{2} \mathrm{O}_{3}+\mathrm{Na}_{3} \mathrm{AlF}_{6}=\mathrm{CrF}_{3}+1.5 \mathrm{Na}_{2} \mathrm{O}+\mathrm{AlF}_{3} \\
1.5 \mathrm{NiO}+\mathrm{Na}_{3} \mathrm{AlF}_{6}=1.5 \mathrm{NiF}_{2}+1.5 \mathrm{Na}_{2} \mathrm{O}+\mathrm{AlF}_{3} \\
0.5 \mathrm{Al}_{2} \mathrm{O}_{3}+\mathrm{Na}_{3} \mathrm{AlF}_{6}=2 \mathrm{AlF}_{3}+1.5 \mathrm{Na}_{2} \mathrm{O}
\end{gathered}
$$
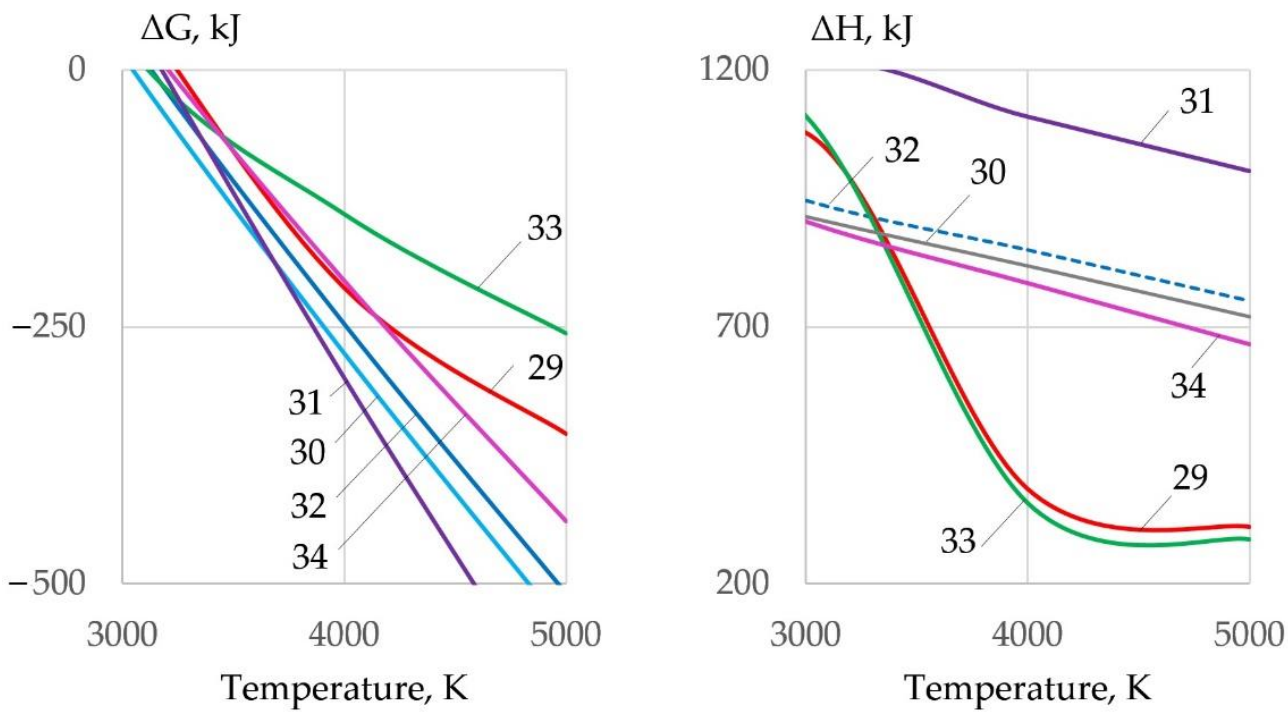

Figure 16. Change of Gibbs free energy and enthalpy of reactions (29-34) of the interaction of oxides with cryolite. 
Endothermic reactions of oxides dissolution in cryolite are possible because the reactions have a negative Gibbs free energy. Spectral analysis of the $\mathrm{Na}_{3} \mathrm{AlF}_{6}-\mathrm{FeO}-\mathrm{Fe}_{2} \mathrm{O}_{3}$ slag system confirm the interaction of iron oxides with cryolite with the formation of iron fluorides and oxyfluoroaluminates, which reduce the surface tension of molten slag [26]. Similar data are presented in [27], which confirms the formation of $\mathrm{FeF}_{2}, \mathrm{FeF}_{3}$, and $\mathrm{Al}_{2} \mathrm{O}_{3}$ fluorides during the interaction of iron oxides with cryolite. Thermodynamic modeling of dissolution of refractory chromium oxide $\mathrm{Cr}_{2} \mathrm{O}_{3}$ in $\mathrm{Na}_{3} \mathrm{AlF}_{6}$ is considered in [28,29]. Dissolution of $\mathrm{Cr}_{2} \mathrm{O}_{3}$ occurs through the interaction with cryolite with the formation of fluoride compounds of chromium and aluminum. Dissolution of $\mathrm{NiO}$ in cryolite also occurs through reactions with the formation of nickel fluorides and aluminum oxide [30]. Dissolution of oxides $\mathrm{CuO}, \mathrm{Cu}_{2} \mathrm{O}$, and $\mathrm{TiO}_{2}$ occurs through the interaction with liquid cryolite with the formation of fluorides $\mathrm{CuF}$ and $\mathrm{CuF}_{2}$ and oxyfluoride $\mathrm{NaTiOF}_{3}[31,32]$.

\subsection{Testing of Flux-Cored Wires}

Flux-cored wires based on $\mathrm{FeCO}_{3}-\mathrm{KNO}_{3}-\mathrm{Na}_{3} \mathrm{AlF}_{6}-\mathrm{Al}$ are effective for cutting various steels and alloys up to $16 \mathrm{~mm}$ thick and potentially over, as shown in Figure 17.

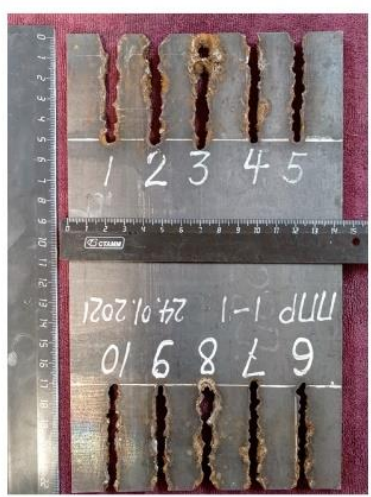

(a)

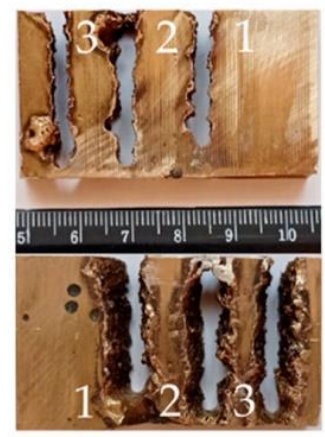

(c)

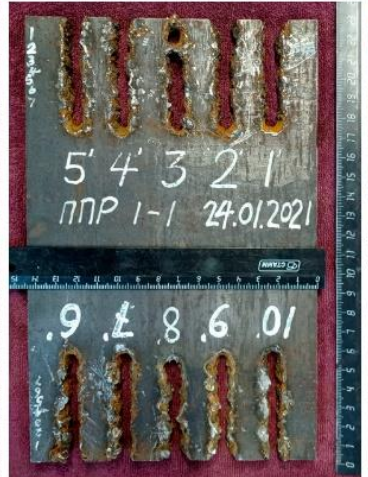

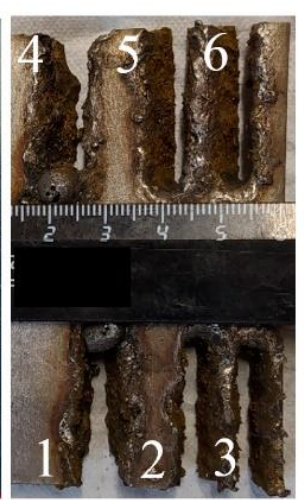

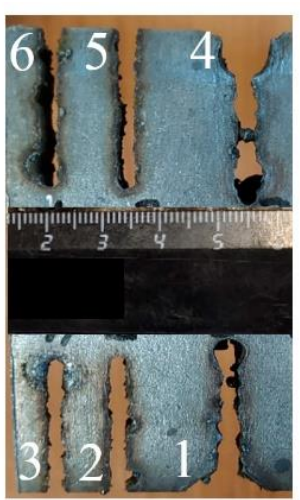

(b)

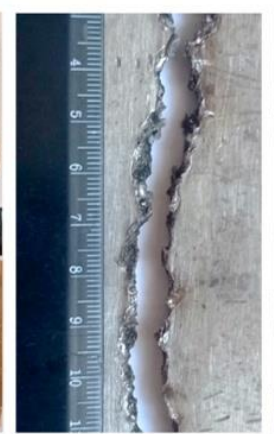

(d)

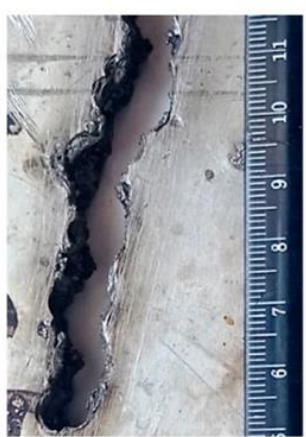

(e)

Figure 17. Outside and backside of the samples after cutting: (a) 10KhSND steel of $10 \mathrm{~mm}$, automatic cutting with PPR-APL1-1; (b) AISI 304L steel of 16 mm, automatic cutting with PPR-APL1-1; (c) CuAl5 alloy of $10 \mathrm{~mm}$, automatic cutting with PPR-APL1-2; (d,e) AlMg4.5Mn0.7 of 6 and $12 \mathrm{~mm}$, semiautomatic cutting with PPR-APL1-3, current of 240 A, voltage of $38 \mathrm{~V}$.

A decrease in the current in the working cycle and an increase in the voltage confirm an increase in the arc length as the arc deepens into the metal, as shown in Figure 18. 
I, A

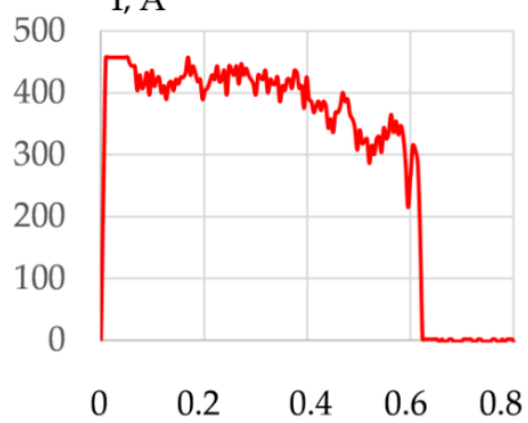

80

$\mathrm{U}, \mathrm{V}$

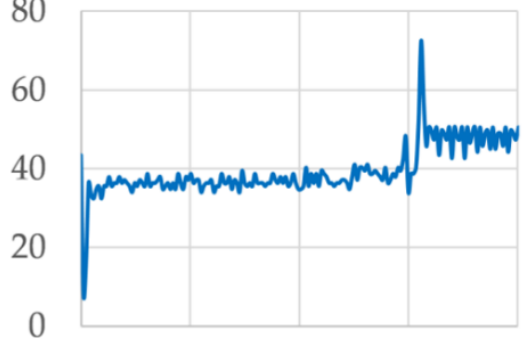

$\begin{array}{lllll}0.2 & 0.4 & 0.6 & 0.8 & \mathrm{t}, \mathrm{s}\end{array}$

Figure 18. Typical change in the current and voltage during a working cycle when cutting $10 \mathrm{KhSND}$ steel with PPR-APL1-1 wire for cut no. 6.

As the wire feed rate increases, the current increases, the short-circuit frequency increases, and the voltage decreases. As the cutting travel speed decreases, the current increases, probably due to the improved arc stability and plasma ionization. The value of current and voltage deviations decreases as the wire feed rate and cutting travel speed increase, as shown in Tables 4-6.

Table 4. Parameters of underwater wet cutting of 10 KhSND steel with PPR-APL1-1 wire.

\begin{tabular}{cccccc}
\hline $\begin{array}{c}\text { Cut } \\
\text { Number }\end{array}$ & I, A & U, V & $\begin{array}{c}\text { Maximal } \\
\text { Working Cycle } \\
\text { Time, s }\end{array}$ & $\begin{array}{c}\text { Maximal } \\
\text { Idle Cycle } \\
\text { Time, s }\end{array}$ & $\begin{array}{c}\text { Short-Circuit } \\
\text { Frequency, Hz }\end{array}$ \\
\hline 1 & $344 \pm 80$ & $38.7 \pm 3.6$ & 3.6 & 1.7 & 0.41 \\
\hline 2 & $371 \pm 67$ & $38 \pm 5.9$ & 4.1 & 1.6 & 0.54 \\
\hline 3 & $417 \pm 43$ & $36.5 \pm 3.9$ & 5 & 1.4 & 0.46 \\
\hline 4 & $411 \pm 35$ & $36.7 \pm 3$ & 2 & 1.2 & 0.78 \\
\hline 5 & $381 \pm 43$ & $38 \pm 3.6$ & 1.5 & 1.1 & 0.81 \\
\hline 6 & $400 \pm 50$ & $36.7 \pm 3$ & 1.8 & 0.6 & 1.23 \\
\hline 7 & $420 \pm 26$ & $36.3 \pm 2.8$ & 1.5 & 1.1 & 1.04 \\
\hline 8 & $377 \pm 35$ & $38.1 \pm 2.6$ & 2.2 & 1.2 & 0.59 \\
\hline 9 & $391 \pm 34$ & $37.5 \pm 3.3$ & 2.9 & 1.2 & 0.49 \\
\hline 10 & $400 \pm 31$ & $37 \pm 1.57$ & 2.2 & 0.7 & 0.89 \\
\hline
\end{tabular}

Table 5. Parameters of underwater wet cutting of AISI 304L steel with PPR-APL1-1 wire.

\begin{tabular}{cccccc}
\hline $\begin{array}{c}\text { Cut } \\
\text { Number }\end{array}$ & I, A & U, V & $\begin{array}{c}\text { Maximal } \\
\text { Working Cycle } \\
\text { Time, s }\end{array}$ & $\begin{array}{c}\text { Maximal } \\
\text { Idle Cycle } \\
\text { Time, s }\end{array}$ & $\begin{array}{c}\text { Short-Circuit } \\
\text { Frequency, Hz }\end{array}$ \\
\hline 1 & $350 \pm 68$ & $39.4 \pm 5.4$ & 3 & 1.2 & 1.3 \\
\hline 2 & $377 \pm 66$ & $37.6 \pm 6.3$ & 0.6 & 0.3 & 2.4 \\
\hline 3 & $389 \pm 68$ & $36.9 \pm 6.1$ & 0.5 & 0.28 & 3.1 \\
\hline 4 & $368 \pm 75$ & $38.4 \pm 5.9$ & 2.5 & 0.8 & 0.8 \\
\hline 5 & $391 \pm 66$ & $37.4 \pm 5.5$ & 1 & 0.53 & 1.8 \\
\hline 6 & $402 \pm 56$ & $36.9 \pm 3.1$ & 0.5 & 0.5 & 2.2 \\
\hline
\end{tabular}


Table 6. Parameters of underwater wet cutting of CuAl5 alloy with PPR-APL1-2 wire.

\begin{tabular}{cccccc}
\hline $\begin{array}{c}\text { Cut } \\
\text { Number }\end{array}$ & I, A & U, V & $\begin{array}{c}\text { Maximal } \\
\text { Working Cycle } \\
\text { Time, s }\end{array}$ & $\begin{array}{c}\text { Maximal } \\
\text { Idle Cycle } \\
\text { Time, s }\end{array}$ & $\begin{array}{c}\text { Short-Circuit } \\
\text { Frequency, Hz }\end{array}$ \\
\hline 1 & $360 \pm 90$ & $37.2 \pm 4.5$ & 2.3 & 0.24 & 1.53 \\
\hline 2 & $375 \pm 85$ & $36.5 \pm 3.5$ & 0.4 & 0.28 & 2.27 \\
\hline 3 & $406 \pm 54$ & $35.4 \pm 1,4$ & 0.6 & 0.35 & 2.93 \\
\hline
\end{tabular}

When cutting 10KhSND steel with flux-cored wires PPR-APL1-1 and PPR-APL1-2 at the cutting speed of $50-70 \mathrm{~mm} / \mathrm{min}$ at the wire feed rate of $9-10 \mathrm{~m} / \mathrm{min}$, the maximum current of 391-420 A with a deviation of $\pm 20-50 \mathrm{~A}$, the minimum voltage of $36.3-37.8 \mathrm{~V}$ with deviations $\pm 1.5-3.2 \mathrm{~V}$ is reached. The analysis of the kerf width and electrical parameters showed that the best stability of cutting 10KhSND steel is achieved at the concentration of the salt mixture at $50-60 \%$ and aluminum at $20-30 \%$, as shown in Figure 19.

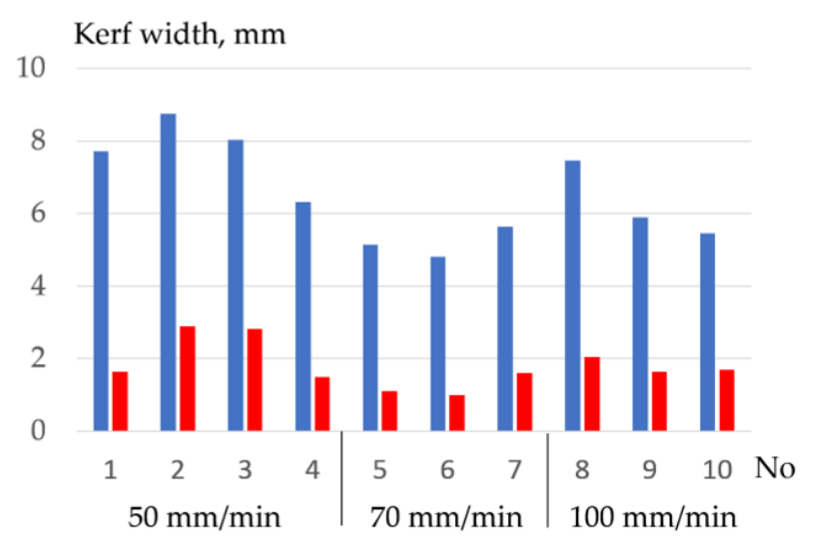

(a)

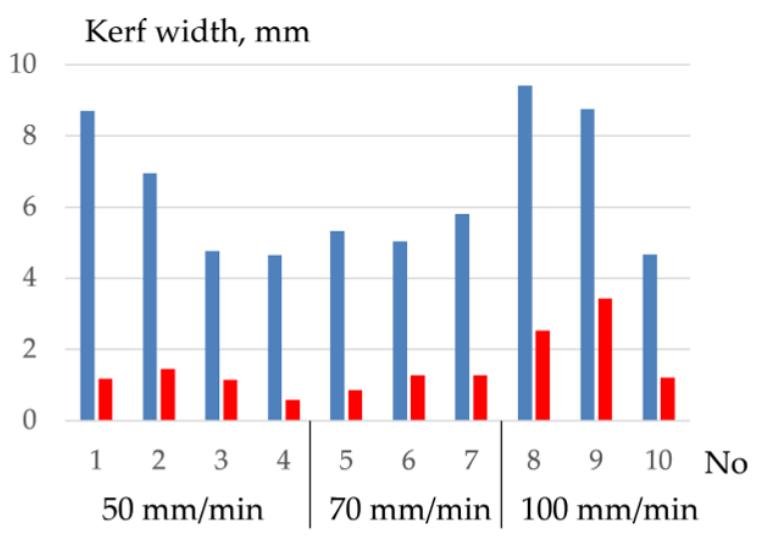

(b)

Figure 19. Variation of the average cutting width and deviations when cutting $10 \mathrm{KhSND}$ steel at speeds of 50, 70, and 100 mm/min: (a) PPR-APL1-1 flux-cored wire; (b) PPR-APL1-2 flux-cored wire.

The hardness measurement method was used to determine the width of the HAZ in the underwater wet cutting of steels $[33,34]$. The results of measuring the hardness and HAZ width are shown in Table 7.

Table 7. Hardness and HAZ width in underwater wet cutting of steels.

\begin{tabular}{|c|c|c|c|c|c|}
\hline \multirow{2}{*}{ Steel } & \multirow{2}{*}{$\begin{array}{l}\text { Travel Speed, } \\
\mathrm{mm} / \mathrm{min}\end{array}$} & \multirow{2}{*}{$\begin{array}{c}\text { Wire Feed Rate, } \\
\mathrm{m} / \mathrm{min}\end{array}$} & \multicolumn{2}{|c|}{ Hardness, HV } & \multirow{2}{*}{ HAZ Width, mm } \\
\hline & & & Base Metal & HAZ & \\
\hline $\begin{array}{c}\text { 10KhSND of } 10 \mathrm{~mm} \\
\text { with PPR-APL1-1 }\end{array}$ & 100 & 10 & $132-157$ & $116-164$ & $4-5.2$ \\
\hline $\begin{array}{c}\text { 10KhSND of } 10 \mathrm{~mm} \\
\text { with PPR-APL1-2 }\end{array}$ & 100 & 10 & $130-163$ & $107-177$ & $4-4.5$ \\
\hline $\begin{array}{c}\text { 10KhSND of } 10 \mathrm{~mm} \\
\text { with PPR-APL1-3 }\end{array}$ & 100 & 10 & $132-158$ & $106-168$ & $6.2-7$ \\
\hline $\begin{array}{l}\text { AISI } 304 \text { of } 16 \mathrm{~mm} \\
\text { with PPR-APL1-1 }\end{array}$ & 100 & 10 & $208-238$ & $249-398$ & $2-2.5$ \\
\hline
\end{tabular}

The minimal HAZ width is achieved in the underwater cutting of steels with $50 \%$ salt mixture and $30 \%$ aluminum in flux-cored wire. 


\section{Conclusions}

1. The mechanism of underwater wet cutting with a flux-cored wire consists of the formation of a kerf in the oxygen atmosphere around the arc's active spot. The formation of the kerf occurs within a pulsating vapor gas bubble under the influence of working cycles with the duration of 1.5-5 s and idle cycles with the duration of 0.6-1.7 s. In underwater cutting of $10 \mathrm{KhSND}$ and $304 \mathrm{~L}$ steel welding, the current was 344-402 A, the voltage was 36-39 V; in cutting of CuAl5 and AlMg4.5Mn0.7 alloy, the welding current was 360-406; $240 \mathrm{~A}$ and the voltage was 35-37; $38 \mathrm{~V}$, respectively, with the optimal composition of flux-cored wire: $50-60 \% \mathrm{FeCO}_{3}$ and $\mathrm{KNO}_{3}, 20-30 \%$ aluminum, $20 \% \mathrm{Na}_{3} \mathrm{AlF}_{6}$.

2. A model of arc penetration and stabilization during underwater wet cutting using flux-cored wires is proposed. The model implies that the formation of the kerf occurs through penetration of the arc into the metal due to oxidation of the metal in a narrow zone around the arc's active spot. The walls of the kerf mechanically compress the arc column, which stabilizes the arc and allows the arc to increase its length as it cuts. The compression of the arc by the walls of the kerf causes increasing ionization, temperature, and pressure of the arc.

3. When metals oxidize, refractory molten slag from oxides of $\mathrm{FeO}, \mathrm{Fe}_{2} \mathrm{O}_{3}, \mathrm{Fe}_{3} \mathrm{O}_{4}, \mathrm{Cr}_{2} \mathrm{O}_{3}$, $\mathrm{NiO}, \mathrm{Cu}_{2} \mathrm{O}$, and $\mathrm{Al}_{2} \mathrm{O}_{3}$ forms on the inner surface of the kerf at the temperature of $1000-4000 \mathrm{~K}$, isolating the metal from oxygen and hindering the cutting process. The slag is forced out by the forces of gravity, arc pressure, and surface tension. To remove the slag, it was proposed to reduce the surface tension of the slag through ionic dissolution and interaction of refractory oxides in $\mathrm{Na}_{3} \mathrm{AlF}_{6}$ cryolite when the change of Gibbs free energy occurs from $-140 \mathrm{~kJ}$ to $-300 \mathrm{~kJ}$ at the temperature of $4000 \mathrm{~K}$.

4. Oxidizing cutting requires the composition of the gas mixture with high oxygen amount of up to $0.2-0.4$ mole fraction at the temperature of $4000 \mathrm{~K}$ in the cutting zone, with electrons amounting up to $0.18-0.3$ mole fraction at the temperature of $10,000 \mathrm{~K}$, negative ions of oxygen and fluor less than 0.002 and 0.0018 mole fraction, enthalpy of more than $5 \mathrm{~kJ} / \mathrm{kg}$, heat capacity of more than $5.5 \mathrm{~J} / \mathrm{kg} \cdot \mathrm{K}$, and thermal conductivity of plasma more than $0.4 \mathrm{~W} / \mathrm{m} \cdot \mathrm{K}$ at a temperature of $4000 \mathrm{~K}$. These conditions are satisfied by the proposed oxidizing mixtures: $40-80 \%$ of $\mathrm{KNO}_{3}, \mathrm{NaNO}_{3}$, iron carbonate $\mathrm{FeCO}_{3}$, and $10-40 \%$ aluminum.

5. The exothermic effect allows regulating the thermophysical properties of plasma and can be used in underwater wet cutting. The introduction of $60 \% \mathrm{Fe}_{3} \mathrm{O}_{4}, \mathrm{MoO}_{2}$, and $\mathrm{WO}_{2}$ and $20 \% \mathrm{Al}, \mathrm{Mg}$, and $\mathrm{Ti}$ in exothermic termite mixtures improves plasma ionization, increases electrons amount of up to a 0.3 -mole fraction at the temperature of $10,000 \mathrm{~K}$, reduces the enthalpy of up to $1.5 \mathrm{~kJ} / \mathrm{kg}$ and heat capacity of up to $4.5 \mathrm{~J} / \mathrm{kg} \cdot \mathrm{K}$, and increases the thermal conductivity of plasma of up to $1.16 \mathrm{~W} / \mathrm{m} \cdot \mathrm{K}$ at the temperature of $4000 \mathrm{~K}$.

6. Flux-cored wires with an oxidizing mixture are effective for cutting low-alloyed stainless steel as well as for cutting bronze and aluminum alloys. The optimum content of salts $\mathrm{KNO}_{3}$ and $\mathrm{FeCO}_{3}$ in the experimental wire was $50-60 \%$ with the introduction of $20-30 \%$ aluminum and $20 \% \mathrm{Na}_{3} \mathrm{AlF}_{6}$. This composition allowed achieving stable cutting of 10KhSND steel with the kerf width of up to $4.7 \mathrm{~mm}$, AISI $304 \mathrm{~L}$ steel with the kerf width of up to $2.5 \mathrm{~mm}$, and CuAl5 bronze with the kerf width of up to $3 \mathrm{~mm}$ with a deviation of $\pm 0.3 \mathrm{~mm}$.

Author Contributions: Conceptualization, S.G.P.; methodology, S.G.P. and A.M.L.; software, S.G.P.; validation, S.G.P. and A.M.L.; formal analysis, P.W.; investigation, S.G.P. and P.W.; resources, A.M.L.; data curation, A.M.L.; writing-original draft preparation, S.G.P.; writing-review and editing, A.M.L.; visualization, S.G.P.; supervision, S.G.P.; project administration, A.M.L.; funding acquisition, A.M.L. All authors have read and agreed to the published version of the manuscript.

Funding: This research received no external funding.

Institutional Review Board Statement: Not applicable. 
Informed Consent Statement: Not applicable.

Data Availability Statement: Data sharing is not applicable.

Acknowledgments: This research was supported by the Educational Scientific and Technical Center "Svarka", St. Petersburg, Russia.

Conflicts of Interest: The authors declare no conflict of interest.

\section{References}

1. Frazer, I.; Gibson, O.J.; Fyffe, L.; Lucas, B. Remotely operated underwater thermal cutting processes for the decommissioning of large North Sea platforms. In Proceedings of the OMAE'02 21st International Conference on Offshore Mechanics and Arctic Engineering, Oslo, Norway, 23-28 June 2002; pp. 1-9.

2. Arias, R.; Bracarense, A.Q. Fatigue crack growth assessment in underwater wet welds. Weld. J. 2017, 8, $287-294$.

3. Tomków, J.; Fydrych, D.; Rogalski, G. Role of bead sequence in underwater welding. Materials 2019, 12, 3372. [CrossRef] [PubMed]

4. Klett, J.; Hecht-Linowitzki, V.; Grünzel, O.; Schmidt, E.; Maier, H.J.; Hassel, T. Effect of the water depth on the hydrogen content in SMAW wet welded joints. SN Appl. Sci. 2020, 2, 1-14. [CrossRef]

5. Świerczyńska, A.; Fydrych, D.; Rogalski, G. Diffusible hydrogen management in underwater wet self-shielded flux cored arc welding. Int. J. Hydrogen Energy 2017, 42, 24532-24540. [CrossRef]

6. Kononenko, V.Y. Underwater Welding and Cutting; Ukraine University: Kiev, Ukraine, 2011; pp. 200-244. (In Russian)

7. Li, W.; Zhao, J.; Wang, J.; Wang, J.; Jia, H.; Li, Z.; Maksimov, S.Y. Research on arc cutting mechanism and procedure of flux-cored cutting wire in water. Int. J. Adv. Manuf. Technol. 2018, 98, 2895-2904. [CrossRef]

8. Hilton, P.A.; Khan, A. Underwater cutting using a $1 \mu \mathrm{m}$ laser source. J. Laser Appl. 2015, 27, 032013. [CrossRef]

9. Wang, J.Y.; He, C.H.; Li, W.H.; Yang, F. Characteristics of underwater swirling plasma arc cut quality. Adv. Mater. Res. 2010, 97-101, 3974-3977. [CrossRef]

10. Bach, F.-W.; Lindemaier, J.; Philipp, E.; Versemann, R. Contact arc metal cutting-Introduction of an extraordinary underwater cutting technology. Weld. World 1998, 41, 132-137.

11. Gretskiy, Y.Y.; Nefedov, Y.N. Study of peculiarities of underwater flux-cored wire arc cutting without additional supply of oxygen. In Underwater Wet Welding and Cutting; Woodhead Publishing: Cambridge, UK, 1998; pp. 87-95.

12. Nefedov, Y.N.; Danchenko, M.E. Technology and experience of application of underwater flux-cored wire arc semi-automatic cutting. In Underwater Wet Welding and Cutting; Woodhead Publishing: Cambridge, UK, 1998; pp. 96-104.

13. Danchenko, M.E.; Gretskiy, Y.Y.; Savich, I.M.; Golovko, N.V. Flux-Cored Wire for Underwater Cutting; Certificate for Invention of the USSR No. 1718501; USSR State Committee for Inventions and Discoveries: Moscow, Russia, 1989. (In Russian)

14. Danchenko, M.E.; Savich, I.M.; Golovko, N.V. Flux-Cored Wire for Underwater Cutting; Certificate for Invention of the USSR No. 1358254; USSR State Committee for Inventions and Discoveries: Moscow, Russia, 1995. (In Russian)

15. Grishanov, A.A.; Pankov, V.I. Flux-Cored Wire for Underwater Cutting; Certificate for Invention of the USSR No. 2113960; USSR State Committee for Inventions and Discoveries: Moscow, Russia, 1998. (In Russian)

16. Liu, D.; Li, H.; Feng, J.; Guo, N.; Liu, J. Chemical Core Cutting Wire for Underwater Wet Method Electric Arc Cutting. China Patent No. CN104858565A, 26 August 2015.

17. Wang, J.; Wang, J.; Li, W.; Zhu, J. Flux-Cored Cutting Wire for Underwater Wet-Type Arc Cutting and Preparation Method Thereof. China Patent No. CN102554520A, 11 July 2012.

18. Liu, D.; Lia, H.; Yan, Y.; Guo, N.; Song, X.; Feng, J. Effects of processing parameters on arc stability and cutting quality in underwater wet flux-cored arc cutting at shallow water. J. Manuf. Process. 2018, 33, 24-34. [CrossRef]

19. Li, W.; Wang, H.; Yu, R.; Wang, J.; Wang, J.; Wu, M.; Maksimov, S.Y. High-speed photography analysis for underwater flux-cored wire arc cutting process. In Transactions on Intelligent Welding Manufacturing; Springer Nature Singapore Pte Ltd.: Singapore, 2020; pp. 141-150.

20. Li, W.; Zhao, J.; Wang, Y.; Wang, J.; Wang, J.; Jia, H.; Li, Z.; Wu, J.; Li, W. Research on underwater flux cored arc cutting mechanism based on simulation of kerf formation. J. Manuf. Process. 2019, 40, 169-177. [CrossRef]

21. Wang, J.; Shi, J.; Wang, J.; Li, W.; Liu, C.; Xu, G.; Maksimov, S.Y.; Zhu, Q. Numerical study on the temperature field of underwater flux-cored wire arc cutting process. Int. J. Adv. Manuf. Technol. 2017, 91, 2777-2786. [CrossRef]

22. Parshin, S.G.; Levchenko, A.M.; Maystro, A.S. Metallurgical model of diffusible hydrogen and non-metallic slag inclusions in underwater wet welding of high-strength steel. Metals 2020, 10, 1498. [CrossRef]

23. Parshin, S.; Levchenko, A.; Wang, P.; Maystro, A. Mathematical analysis of the influence of the flux-cored wire chemical composition on the electrical parameters and quality in the underwater wet cutting. Adv. Mater. Sci. 2021, 21, 77-89. [CrossRef]

24. Parshin, S.; Levchenko, A. Technology and equipment for underwater wet welding and cutting of high strength steel arctic structures using flux-cored wires. In IOP Conference Series: Earth and Environmental Science; IOP Publishing Ltd.: Bristol, UK, 2020.

25. Li, H.L.; Liu, D.; Guo, N.; Chen, H.; Du, Y.P.; Feng, J.C. The effect of alumino-thermic addition on underwater wet welding process stability. J. Mater. Process. Technol. 2017, 245, 149-156. [CrossRef]

26. Simko, F.; Rakhmatullin, A.; Boca, M.; Danek, V.; Bessada, C. A high-temperature multinuclear $\mathrm{NMR}$ study of $\mathrm{Na}_{3} \mathrm{AlF}_{6}-\mathrm{FeO}_{\text {and }}$ $\mathrm{Na}_{3} \mathrm{AlF}_{6}-\mathrm{Fe}_{2} \mathrm{O}_{3}$ melts. Eur. J. Inorg. Chem. 2006, 22, 4528-4532. [CrossRef] 
27. Dewing, E.W.; Thonstad, J. Solutions of iron oxides in molten cryolite. Metall. Mater. Trans. B 2000, 31, 609-613. [CrossRef]

28. Šuleková, D.; Danielik, V.; Fellner, P.; Thonstad, J. Solubility of chromium(III) oxide in the molten cryolite system. Metall. Mater. Trans. B 2013, 44, 328-331. [CrossRef]

29. Danielik, V.; Fellner, P.; Sulekova, D.; Thonstad, J. Solubility of $\mathrm{Cr}$ species in low temperature cryolite-based electrolyte at $900{ }^{\circ} \mathrm{C}$ J. Electrochem. Soc. 2013, 160, C142-C145. [CrossRef]

30. Jentoftsen, T.E.; Lorentsen, O.-A.; Dewing, E.W.; Haarberg, G.M.; Thonstad, J. Solubility of some transition metal oxides in cryolite-alumina melts: Part I. Solubility of $\mathrm{FeO}, \mathrm{FeAl}_{2} \mathrm{O}_{4}, \mathrm{NiO}$, and $\mathrm{NiAl}_{2} \mathrm{O}_{4}$. Metall. Mater. Trans. B 2002, 33, 901-908. [CrossRef]

31. Lorentsen, O.-A.; Jentoftsen, T.E.; Dewing, E.W.; Thonstad, J. The Solubility of some transition metal oxides in cryolite-alumina melts: Part III. Solubility of $\mathrm{CuO}$ and $\mathrm{Cu}_{2} \mathrm{O}$. Metall. Mater. Trans. B 2007, 38, 833-839. [CrossRef]

32. Zhang, Y.; Rapp, R.A. The solubility of titanium dioxide in cryolite-alumina melts at 1300 K. Metall. Mater. Trans. B 2004, 35, 182-186. [CrossRef]

33. Khalaj, G.; Yoozbashizadeh, H.; Khodabandeh, A.; Tamizifar, M. Austenite grain growth modelling in weld heat affected zone of $\mathrm{Nb} /$ Ti microalloyed linepipe steel. Mater. Sci. Technol. 2014, 30, 424-433. [CrossRef]

34. Pouraliakbar, H.; Khalaj, M.; Nazerfakhari, M.; Khalaj, G. Artificial neural networks for hardness prediction of HAZ with chemical composition and tensile test of X70 pipeline steels. J. Iron Steel Res. Int. 2015, 22, 446-450. [CrossRef] 